\title{
RADIOLOGICAL ASSESSMENT SURVEY \\ OF THE \\ VANCE ROAD FACILITY \\ SOURCE VAULT BUILDING MATERIALS \\ OAK RIDGE INSTITUTE FOR SCIENCE AND EDUCATION \\ OAK RIDGE, TENNESSEE
}

\section{J.R. MORTON}

Prepared for the

Facilities and Transportation Department

Oak Ridge Institute for Science and Education

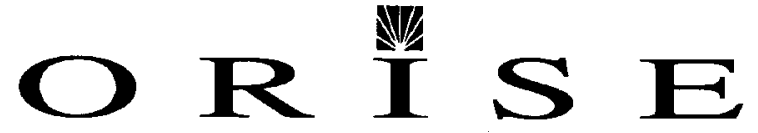

OAK RIDGE INSTITUTE FOR SCIENCE AND EDUCATION

Environmental Survey and Site Assessment

Further dissemination authorized to DOE and DOE contractors only: other requests shall be approved by the originating facility or higher DOE programmatic authority. 
The Oak Ridge Institute for Science and Education (ORISE) was established by the U.S. Department of Energy to undertake national and international programs in education, training, health, and the environment. ORISE and its programs are operated by Oak Ridge Associated Universities (ORAU) through a contract with the U.S. Department of Energy. Established in 1946, ORAU is a consortium of 86 colleges and universities.

\section{NOTICES}

The opinions expressed herein do not necessarily reflect the opinions of the sponsoring institutions of Oak Ridge Associated Universities.

This report was prepared as an account of work sponsored by the United States Government. Neither the United States Government nor the U.S. Department of Energy, nor any of their employees, makes any warranty, expressed or implied, or assumes any legal liability or responsibility for the accuracy, completeness, or usefulness of any information, apparatus, product, or process disclosed, or represents that its use would not infringe on privately owned rights. Reference herein to any specific commercial product, process, or service by trade name, mark, manufacturer, or otherwise, does not necessarily constitute or imply its endorsement or recommendation, or favor by the U.S. Government or any agency thereof. The views and opinions of authors expressed herein do not necessarily state or reflect those of the U.S. Government or any agency thereof. 


\title{
RADIOLOGICAL ASSESSMENT SURVEY \\ OF THE \\ VANCE ROAD FACILITY SOURCE VAULT BUILDING MATERIALS \\ OAK RIDGE INSTITUTE FOR SCIENCE AND EDUCATION \\ OAK RIDGE, TENNESSEE
}

\author{
Prepared by \\ J. R. Morton \\ Environmental Survey and Site Assessment Program \\ Radiological Safety, Assessments, and Training \\ Oak Ridge Institute for Science and Education \\ Oak Ridge, Tennessee 37831-0117
}

Prepared for the

Facilities and Transportation Department

Oak Ridge Institute for Science and Education

FINAL REPORT

\section{SEPTEMBER 2000}

This report is based on work performed under contract DE-AC05-00OR22750 with the U.S. Department of Energy.

Further dissemination authorized to United States Government agencies and their contractors, other requests shall be approved by the originating facility or higher DOE programmatic authority. 


\section{RADIOLOGICAL ASSESSMENT SURVEY \\ OF THE \\ VANCE ROAD FACILITY SOURCE VAULT BUILDING MATERIALS \\ OAK RIDGE INSTITUTE FOR SCIENCE AND EDUCATION \\ OAK RIDGE, TENNESSEE}

Prepared by: $\frac{\text { Ray Morton (Original Signature on File) }}{\text { J. R. Morton, Field Survey Team Leader }}$

Date: $9 / 25 / 00$

Environmental Survey and Site Assessment Program

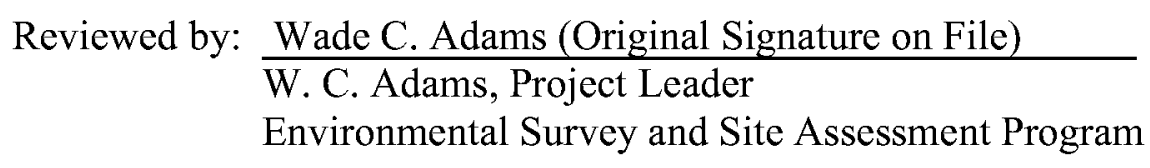

Date: $\quad 9 / 25 / 00$

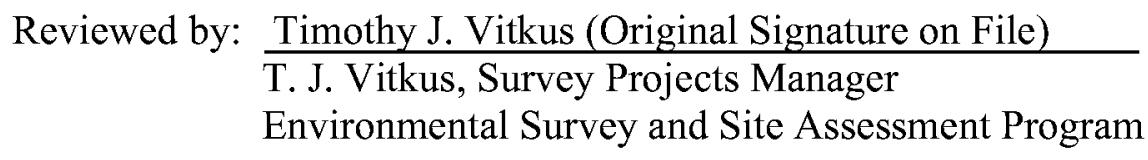

Date: $\underline{10 / 3 / 00}$

Reviewed by: Wade Ivey for (Original Signature on File)

R. D. Condra, Laboratory Manager

Date: $\quad 10 / 3 / 00$

Environmental Survey and Site Assessment Program

Reviewed by: Ann T. Payne (Original Signature on File)

Date: $10 / 3 / 00$

A. T. Payne, Quality Manager

Environmental Survey and Site Assessment Program

Reviewed by: Eric W. Abelquist (Original Signature on File)

E. W. Abelquist, Associate Program Director

Date: $\underline{10 / 3 / 00}$

Environmental Survey and Site Assessment Program

Reviewed by: W.L. Beck (Original Signature on File)

W. L. Beck, Program Director

Date: $10 / 3 / 00$

Environmental Survey and Site Assessment Program 


\title{
ACKNOWLEDGMENTS
}

The author would like to acknowledge the significant contributions of the following staff members:

\author{
LABORATORY STAFF \\ C. M. Brown \\ R. D. Condra \\ J. S. Cox \\ W. P. Ivey
}

\section{CLERICAL STAFF}

D. K. Herrera

K. L. Pond

\section{ILLUSTRATOR}

T. D. Herrera 
PAGE

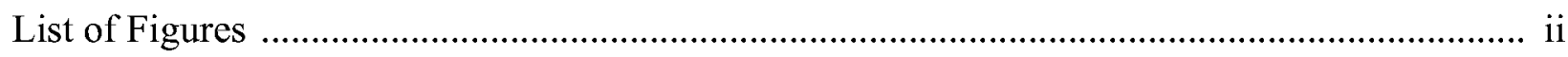

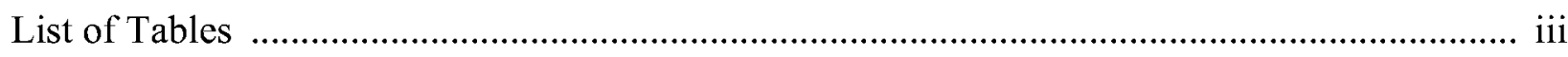

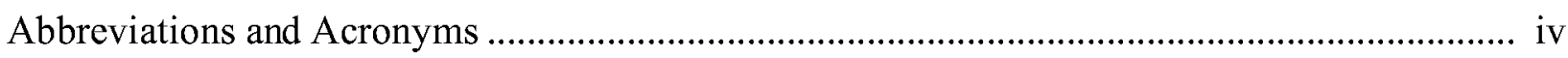

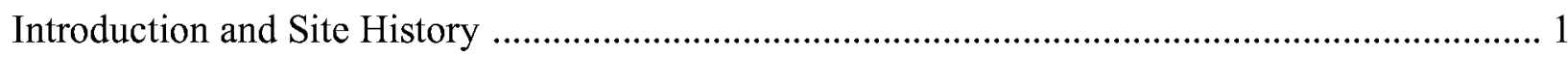

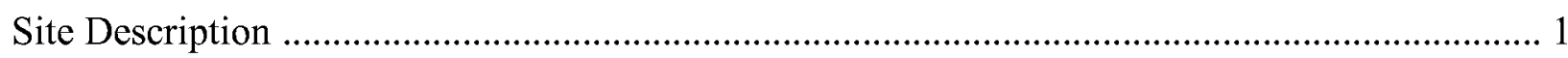

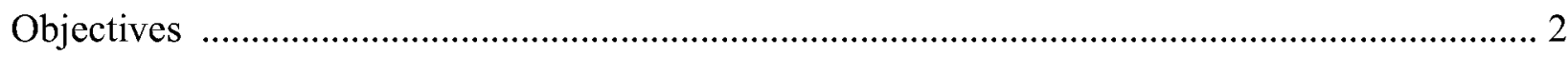

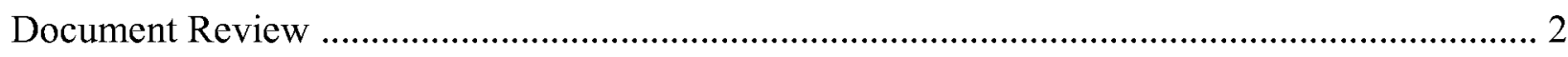

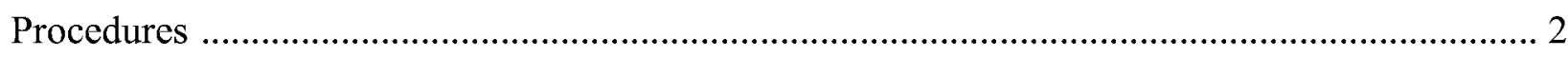

Sample Analysis and Data Interpretation ........................................................................... 4

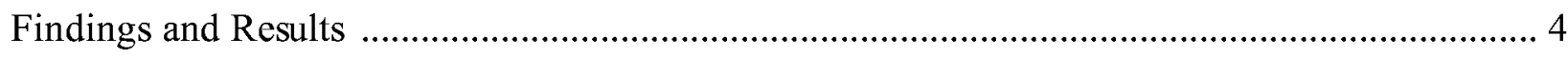

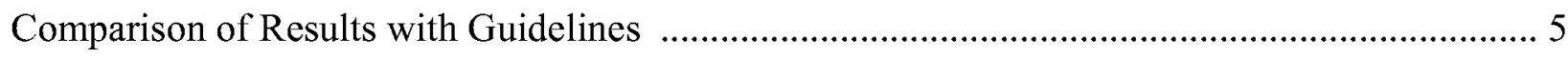

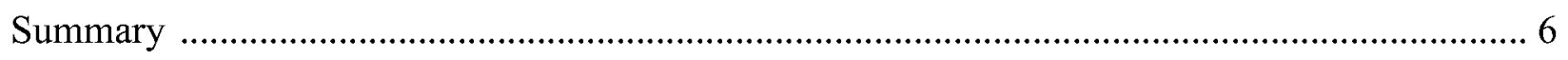

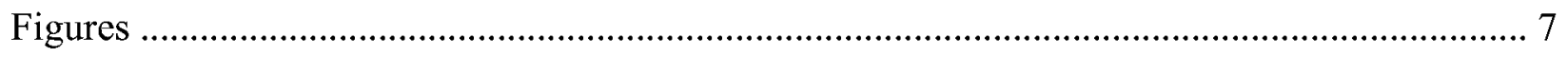

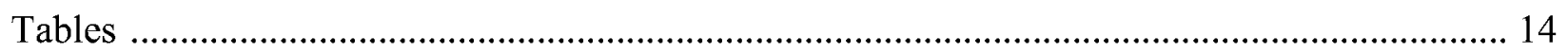

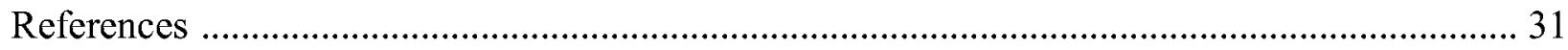

Appendices:

Appendix A: Major Instrumentation

Appendix B: Survey and Analytical Procedures

Appendix C: Summary of Department of Energy Residual Radioactive Material Guidelines 


\section{LIST OF FIGURES}

$\underline{\text { PAGE }}$

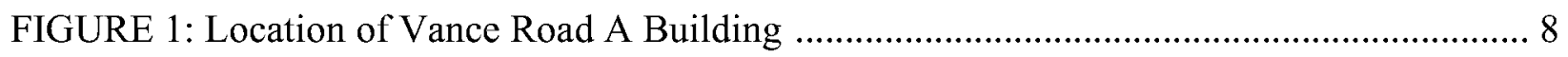

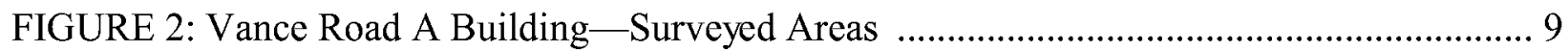

FIGURE 3: Source Vault Area—Presurvey Floor Plan ............................................................. 10

FIGURE 4: Source Vault Area—Elevated Activity Locations ................................................... 11

FIGURE 5: Source Vault Area, A107 — Lower Wall Measurement and Sampling Locations ... 12

FIGURE 6: Source Vault Area, A107a—Lower Wall Measurement and Sampling Locations .. 13 


\section{LIST OF TABLES}

PAGE

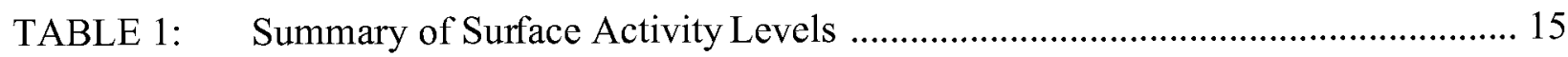




\section{ABBREVIATIONS AND ACRONYMS}

$\begin{array}{ll}\epsilon_{\mathrm{i}} & \text { instrument efficiency } \\ \epsilon_{\mathrm{s}} & \text { source efficiency } \\ \mathrm{b}_{\mathrm{i}} & \text { background counts in observation interval } \\ \mathrm{BKG} & \text { background } \\ \mathrm{cm} & \text { centimeter } \\ \mathrm{cm}^{2} & \text { square centimeter } \\ \mathrm{cpm} & \text { counts per minute } \\ \text { DOE } & \text { U.S. Department of Energy } \\ \mathrm{dpm} & \text { disintegrations per minute } \\ \mathrm{dpm} / 100 \mathrm{~cm}^{2} & \text { disintegrations per minute per 100 square centimeters } \\ \text { EML } & \text { Environmental Measurements Laboratory } \\ \text { ESSAP } & \text { Environmental Survey and Site Assessment Program } \\ \text { FTD } & \text { Facilities and Transportation Department } \\ \text { ITP } & \text { Intercomparison Testing Program } \\ \text { LSC } & \text { liquid scintillation counter } \\ \mathrm{m} & \text { meter } \\ \mathrm{m}^{2} & \text { square meter } \\ \text { mm } & \text { millimeter } \\ \text { MAPEP } & \text { Mixed Analyte Performance Evaluation Program } \\ \text { MDC } & \text { minimum detectable concentration } \\ \text { MDCR } & \text { minimum detectable count rate } \\ \text { NIST } & \text { National Institute of Standards and Technology } \\ \text { NRC } & \text { U.S. Nuclear Regulatory Commission } \\ \text { NRIP } & \text { NIST Radiochemistry Intercomparison Program } \\ \text { ORISE } & \text { Oak Ridge Institute for Science and Education } \\ \text { ORO } & \text { Oak Ridge Operations } \\ \text { RA } & \text { remedial action } \\ \mathrm{s} & \text { seconds } \\ \text { SEPD } & \text { Safety and Environmental Protection Department } \\ \text { SVA } & \text { Source Vault Area } \\ \text { VRF } & \text { Vance Road Facility } \\ & \end{array}$




\section{RADIOLOGICAL ASSESSMENT SURVEY \\ OF THE \\ VANCE ROAD FACILITY SOURCE VAULT BUILDING MATERIALS \\ OAK RIDGE INSTITUTE FOR SCIENCE AND EDUCATION \\ OAK RIDGE, TENNESSEE}

\section{INTRODUCTION AND SITE HISTORY}

The Oak Ridge Institute for Science and Education (ORISE) occupies and maintains, on behalf of the Department of Energy's Oak Ridge Operations Office (DOE-ORO), the Vance Road Facility (VRF). Several radiological research laboratories formerly operated on the second floor of the VRF. These laboratories were used since the early 1950's for medical research activities involving both sealed and unsealed sources of a variety of radionuclides. Radionuclides such as ${ }^{3} \mathrm{H},{ }^{14} \mathrm{C},{ }^{90} \mathrm{Sr},{ }^{67} \mathrm{Ga},{ }^{68} \mathrm{Ga},{ }^{68} \mathrm{Ge},{ }^{60} \mathrm{Co},{ }^{44} \mathrm{Sc} /{ }^{44} \mathrm{Ti},{ }^{137} \mathrm{Cs}$, and ${ }^{226} \mathrm{Ra}$ were used in these laboratories along with other rare radionuclides, such as some short-lived alpha and beta emitters that have most likely decayed away. The radionuclides used in these laboratories were stored in a source vault located on the first floor of the facility. Prior to this survey, the Source Vault Area (SVA) was converted into two laboratories which were identified as Rooms A107 and A107a. In 1997, the Facilities and Transportation Department (FTD) of ORISE remediated the second floor laboratories and converted them to office space. FTD has now requested that the Environmental Survey and Site Assessment Program (ESSAP) of ORISE perform a radiological assessment survey of the SVA and its associated miscellaneous building materials and laboratory equipment.

\section{SITE DESCRIPTION}

The VRF is located at 140 East Vance Road and is west of the Methodist Medical Center Hospital in Oak Ridge (Figure 1). The SVA is located in the far northwest end of the ground floor of the VRF A Building (Figure 2). The SVA consisted of two small rooms (Rooms A107 and A107a) with tile and vinyl floor coverings over a poured concrete base and walls constructed of wood framing with splash-proof wall panels (Figure 3). There was a false ceiling in place consisting of standard-sized panels and the corresponding metal hanging system that covered the duct systems. Equipment, including sinks, tables, shelves, and a refrigerator occupied approximately $25 \%$ of the available floor space. The SVA contained drain lines, three hoods, 
and hood vent ductwork with the hood vent exhausts located on the roof. The three hoods were not removed during these surveys and will be addressed at a later date. The room also contained various sinks, countertops, and other miscellaneous equipment.

\section{OBJECTIVE}

The objective of this survey was to obtain sufficient data to evaluate the radiological condition of the removable materials and equipment within the SVA.

\section{DOCUMENT REVIEW}

As part of the remedial action activities, ESSAP reviewed available historical information regarding radionuclide usage within the facility.

\section{PROCEDURES}

During the period of March through July, 2000, ESSAP performed a remedial action release survey of the SVA. The radiological surveys involved the scanning of each individual piece of equipment/material prior to its removal from the SVA. Once the determination was made that the items had no residual activity, the materials were removed from the room and disposed of accordingly. Any materials found to possess elevated residual contamination were remediated or packaged properly prior to their removal from the SVA. Survey activities were conducted in accordance with a plan dated March 14, 2000 and the ORISE/ESSAP Survey Procedures and Quality Assurance Manuals (ORISE 2000a, 1998, and 2000b). Deviations to the survey plan were made as the survey progressed and were recorded in the site logbook.

\section{BaCKground Measurements}

Material-specific direct measurement backgrounds were performed on similar material types, but without a history of radioactive material use. These background measurements were used to correct gross surface activity measurements. 


\section{Radiological Assessment Survey Procedures}

Radiological assessment survey procedures applied to the temporary walls, floor coverings, false ceiling, hood ductwork, and equipment that were removed from the SVA.

\section{Reference Locations}

Measurement and sampling locations of the temporary walls removed from within the SVA were referenced to scaled drawings. Measurement location for other miscellaneous items (such as floor coverings, the false ceiling, sinks, benchtops, cabinets, etc.) removed from the SVA were only documented on the survey sheets by a description of the item and measurement location. Locations with residual contamination approaching or exceeding guidelines were also indicated on the scaled drawings.

\section{$\underline{\text { Surface Scans }}$}

Surface scans for alpha plus beta activity were performed on $100 \%$ of all accessible surfaces of the building material/equipment using hand-held gas proportional detectors coupled to ratemeter-scalers with audible indicators. After the equipment had been removed from its original position, the previously inaccessible areas were also scanned at a rate of $100 \%$. This process included the scans of the vinyl floor surface which covered up to two layers of floor tiles. Each tile was removed and scanned on both sides. Any pieces of vinyl flooring or tiles exhibiting surface activity greater than the release criteria via these scans were disposed of as radiological waste, while those exhibiting surface activity levels less than the criteria were removed from the SVA. Particular attention was given to locations where residual material may have accumulated. Locations of elevated direct radiation identified during the survey activities were marked for remedial action (Figure 4).

\section{$\underline{\text { Surface Activity Measurements }}$}

Direct measurements for alpha and beta surface activity levels were obtained from 199 locations on the removed walls, flooring, building materials, equipment, etc. Figures 5 and 6 depict the 
measurement locations performed on the removed walls. Direct measurements were not performed on a large portion of the building materials - the pieces were discarded in regular trash when no elevated activity was detected by scans or smear sampling or as radiological waste when contamination was identified. All measurements were performed using hand-held gasproportional detectors coupled to ratemeter-scalers. Smears for determining removable gross alpha and gross beta contamination were collected at each direct measurement location exhibiting elevated activity. A separate set of smears was also collected at suspect or randomly selected locations to determine removable ${ }^{3} \mathrm{H}$ and ${ }^{14} \mathrm{C}$ contamination, as the sensitivity of the field instrumentation was not adequate to detect the low-energy beta emissions of these radionuclides.

\section{SAMPLE ANALYSIS AND DATA INTERPRETATION}

Samples and survey data were returned to the ESSAP Oak Ridge laboratory for analysis and interpretation. Sample analyses were performed in accordance with the ESSAP Laboratory Procedures Manual (ORISE 2000c). Smears were analyzed for gross alpha and gross beta activity using a low background gas proportional counter and for ${ }^{3} \mathrm{H},{ }^{14} \mathrm{C}$, and ${ }^{90} \mathrm{Sr}$ using a liquid scintillation counter (LSC). The conversion of the LSC data for ${ }^{90} \mathrm{Sr}$ was not performed on all samples, just those with ratios indicating the presence of the radionuclide. Direct measurement and smear data were converted to units of disintegrations per minute per 100 square centimeters $\left(\mathrm{dpm} / 100 \mathrm{~cm}^{2}\right)$. The data generated was compared with the DOE (as specified in DOE Order 5400.5) and U.S. Nuclear Regulatory Commission (NRC) guidelines.

\section{FINDINGS AND RESULTS}

\section{Document Review}

Historical data submitted for review by the Safety and Environmental Protection Department (SEPD) was limited to previous radiological laboratory survey data (maps and measurement locations) indicating the radionuclides that had been used during that time period. 


\section{Surface Scans}

Surface scans identified four locations of residual elevated activity on the shelves and cabinets, three locations on the sheetrock walls, four on the false ceiling tiles, and approximately a dozen on the vinyl flooring which had residual elevated activity in excess of the release guidelines. Additionally, 13 of the 14 surveyed pieces of hood ductwork and numerous pieces of floor tile and other miscellaneous parts of equipment (lead bricks, baseboard, etc.) were identified as having residual elevated surface activity.

\section{Surface Activity Levels}

Results of the total and removable surface activity levels for the radiological assessment survey are presented in Table 1. Total surface activity levels ranged from -8 to $48 \mathrm{dpm} / 100 \mathrm{~cm}^{2}$ and 180 to $280,000 \mathrm{dpm} / 100 \mathrm{~cm}^{2}$ for alpha and beta, respectively. Removable activity levels ranged from 0 to $13 \mathrm{dpm} / 100 \mathrm{~cm}^{2}$ for gross alpha, -5 to $2,500 \mathrm{dpm} / 100 \mathrm{~cm}^{2}$ for gross beta, -7 to 42,700 dpm/100 $\mathrm{cm}^{2}$ for ${ }^{3} \mathrm{H}$, -9 to $81,770 \mathrm{dpm} / 100 \mathrm{~cm}^{2}$ for ${ }^{14} \mathrm{C}$, and -12 to $72,400 \mathrm{dpm} / 100 \mathrm{~cm}^{2}$ for ${ }^{90} \mathrm{Sr}$.

\section{COMPARISON OF RESULTS WITH GUIDELINES}

The radionuclides of concern at VRF's Source Vault Area were ${ }^{3} \mathrm{H},{ }^{14} \mathrm{C},{ }^{90} \mathrm{Sr}$, and ${ }^{226} \mathrm{Ra}$. The DOE guidelines for residual radioactive materials and the current NRC guidelines for acceptable surface contamination levels for release of a facility for unrestricted use were considered, and in cases when these guidelines were not identical, the more conservative values were used to evaluate the survey results. The primary beta contaminants of concern were ${ }^{90} \mathrm{Sr},{ }^{60} \mathrm{Co}$, and ${ }^{14} \mathrm{C}$. The more restrictive beta contamination guideline for ${ }^{90} \mathrm{Sr}$ was used for comparing direct beta surface activity levels (DOE 1990).

\section{${ }^{3} \underline{\text { H Removable Activity }}$}

$$
10,000 \mathrm{dpm} / 100 \mathrm{~cm}^{2}
$$


$\underline{\text { Total Alpha Activity }}$

$100 \mathrm{dpm} / 100 \mathrm{~cm}^{2}$ (Average over $1 \mathrm{~m}^{2}$ )

$300 \mathrm{dpm} / 100 \mathrm{~cm}^{2}$ (Maximum in $100 \mathrm{~cm}^{2}$ )

$20 \mathrm{dpm} / 100 \mathrm{~cm}^{2}$ (Removable in $100 \mathrm{~cm}^{2}$ )

Beta-Gamma Activity

1,000 dpm/100 $\mathrm{cm}^{2}$ (Average over $1 \mathrm{~m}^{2}$ )

$3,000 \mathrm{dpm} / 100 \mathrm{~cm}^{2}$ (Maximum in $100 \mathrm{~cm}^{2}$ )

$200 \mathrm{dpm} / 100 \mathrm{~cm}^{2}$ (Removable in $100 \mathrm{~cm}^{2}$ )

The surface activity guidelines in DOE Order 5400.5 do not specifically address tritium. Because tritium typically penetrates the materials in which in comes into contact, the betagamma emitter surface activity guidelines are not applicable. Therefore, DOE assessed the potential doses associated with the release of property containing residual tritium and recommended an interim value of $10,000 \mathrm{dpm} / 100 \mathrm{~cm}^{2}$ for removable tritium (DOE 1995).

During the remedial action surveys, several of the removed pieces of equipment and building materials possessed residual activity in excess of the guidelines - these areas were remediated to allow for the removal of the pieces as the survey progressed.

\section{SUMMARY}

During the period of March through July 2000, the Environmental Survey and Site Assessment Program performed a remedial action survey of the Source Vault Area of the Oak Ridge Institute for Science and Education's Vance Road Facility.

The radiological assessment survey activities included surface scans, surface activity measurements, and smear sampling of the building materials and equipment which was being removed from the area to allow access to the structural surfaces. Many of the materials had areas of residual radioactive material that exceeded the release criteria for either surface or removable activity and were therefore, remediated accordingly. Once remedial activities were completed, the non-suspect pieces and the remediated portions of the pieces with activity levels exceeding criteria were removed from the SVA. 


\section{FIGURES}




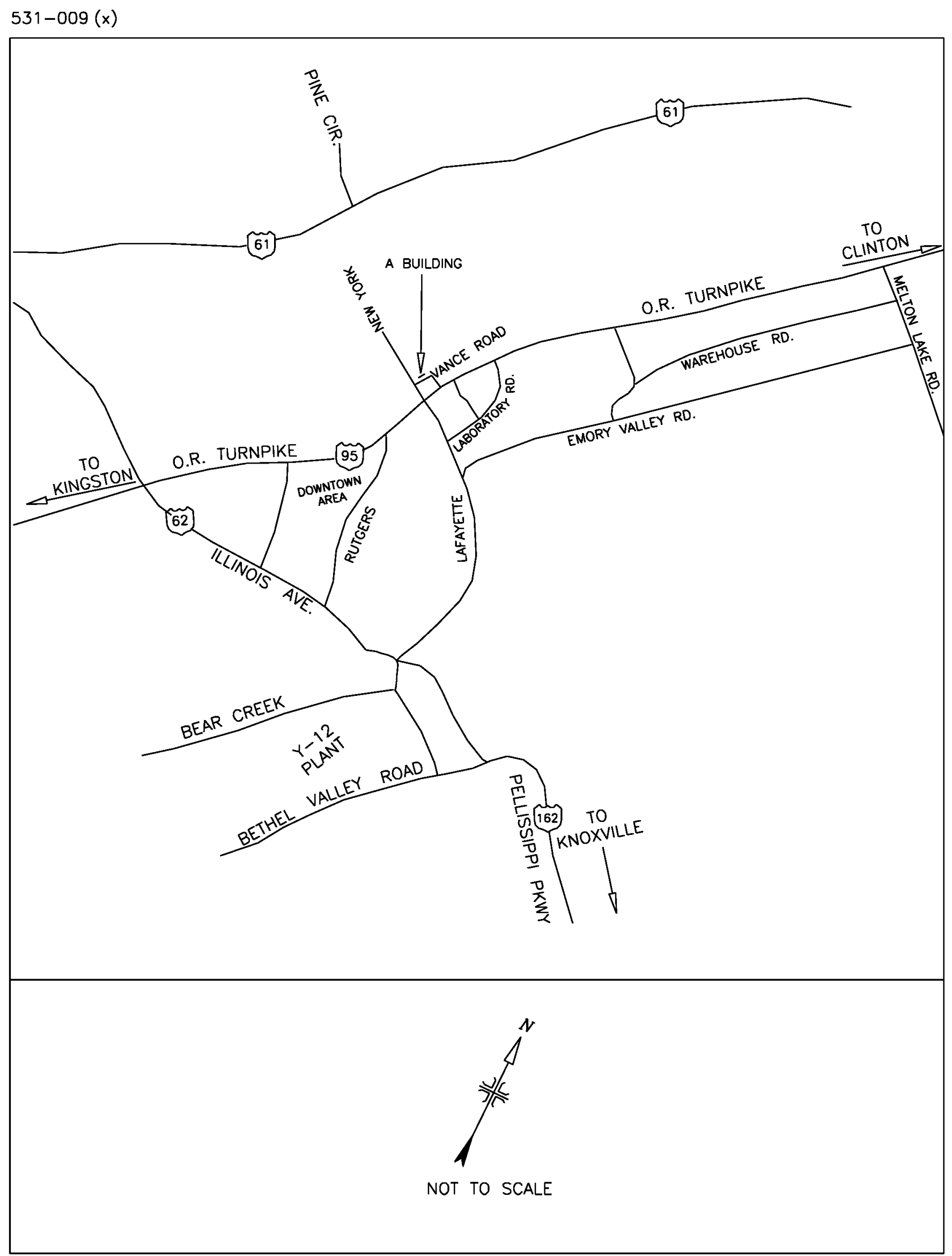

FIGURE 1: Location of Vance Road A Building 


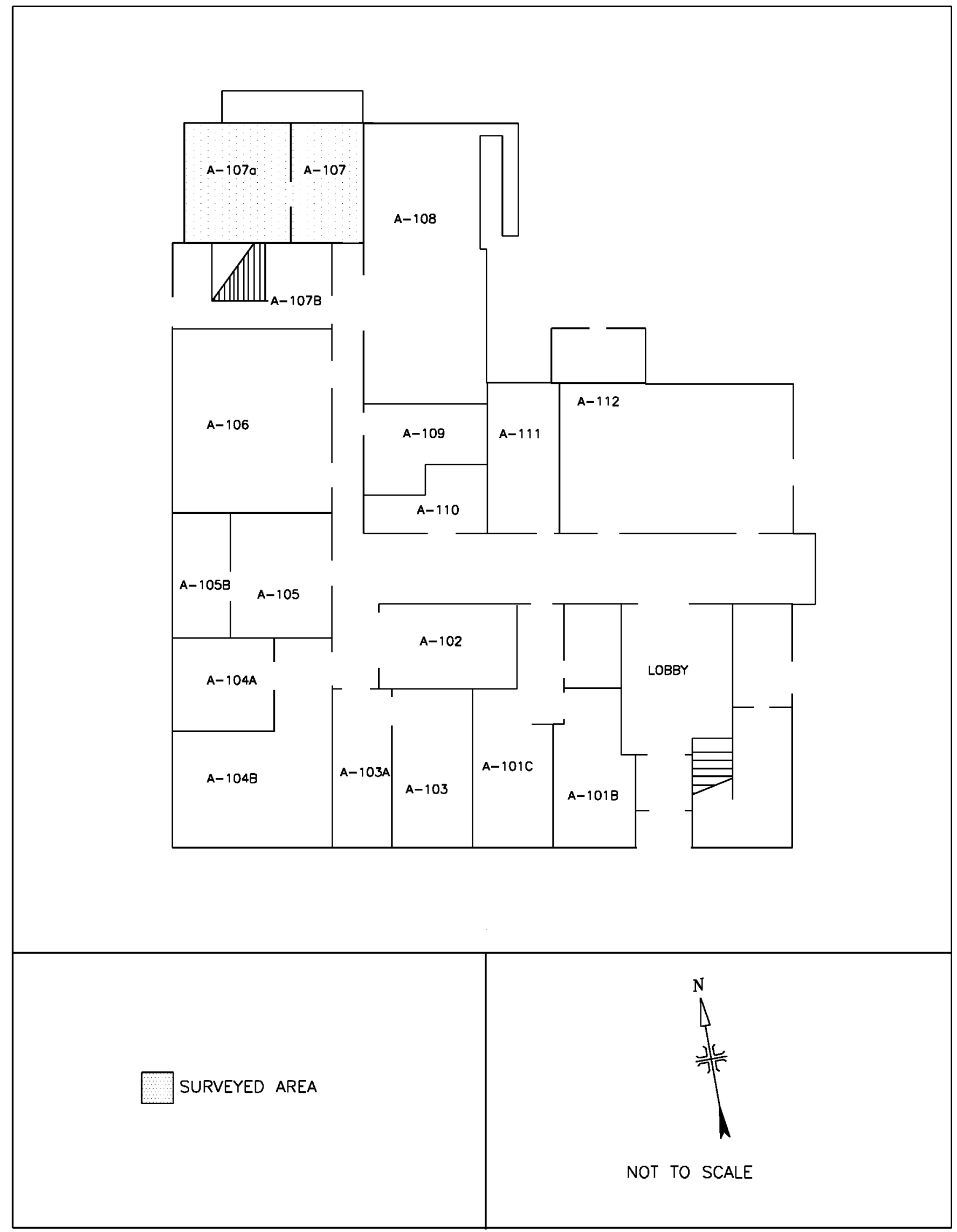

FIGURE 2: Vance Road A Building - Surveyed Areas 


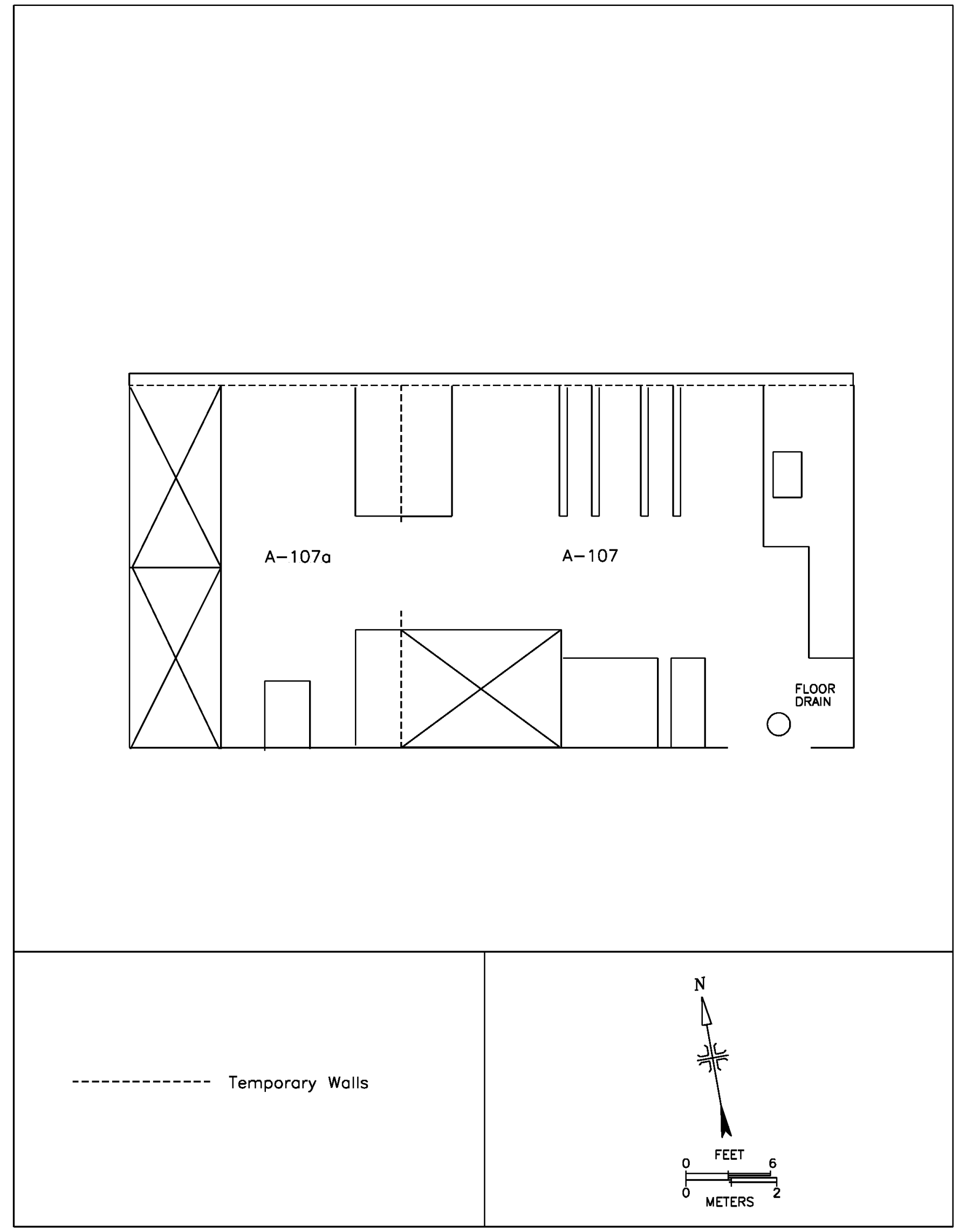

FIGURE 3: Source Vault Area - Presurvey Floor Plan 

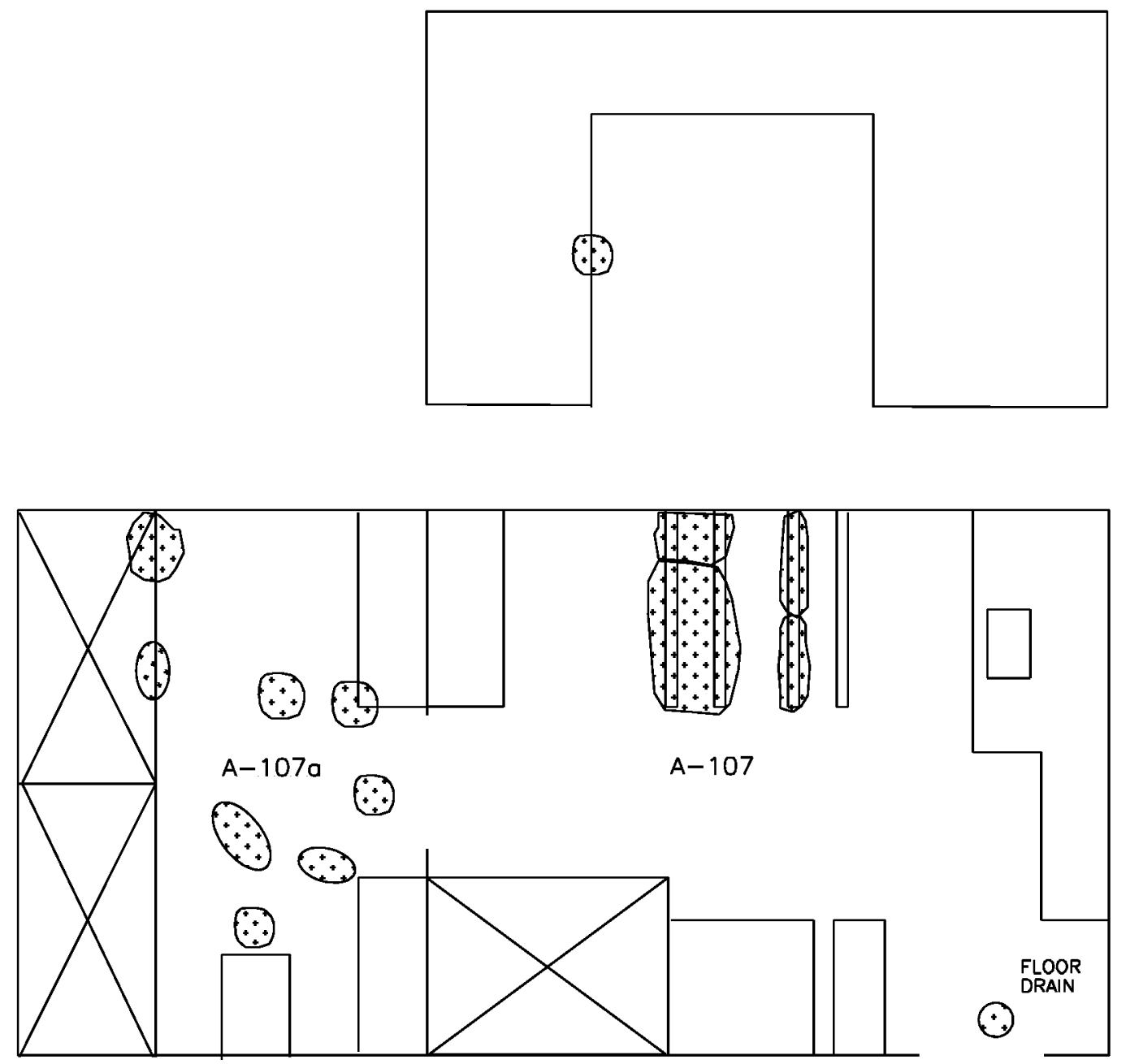

$+\div$ EleVated ACTIVITY

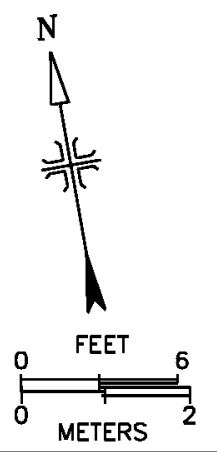

FIGURE 4: Source Vault Area - Elevated Activity Locations 

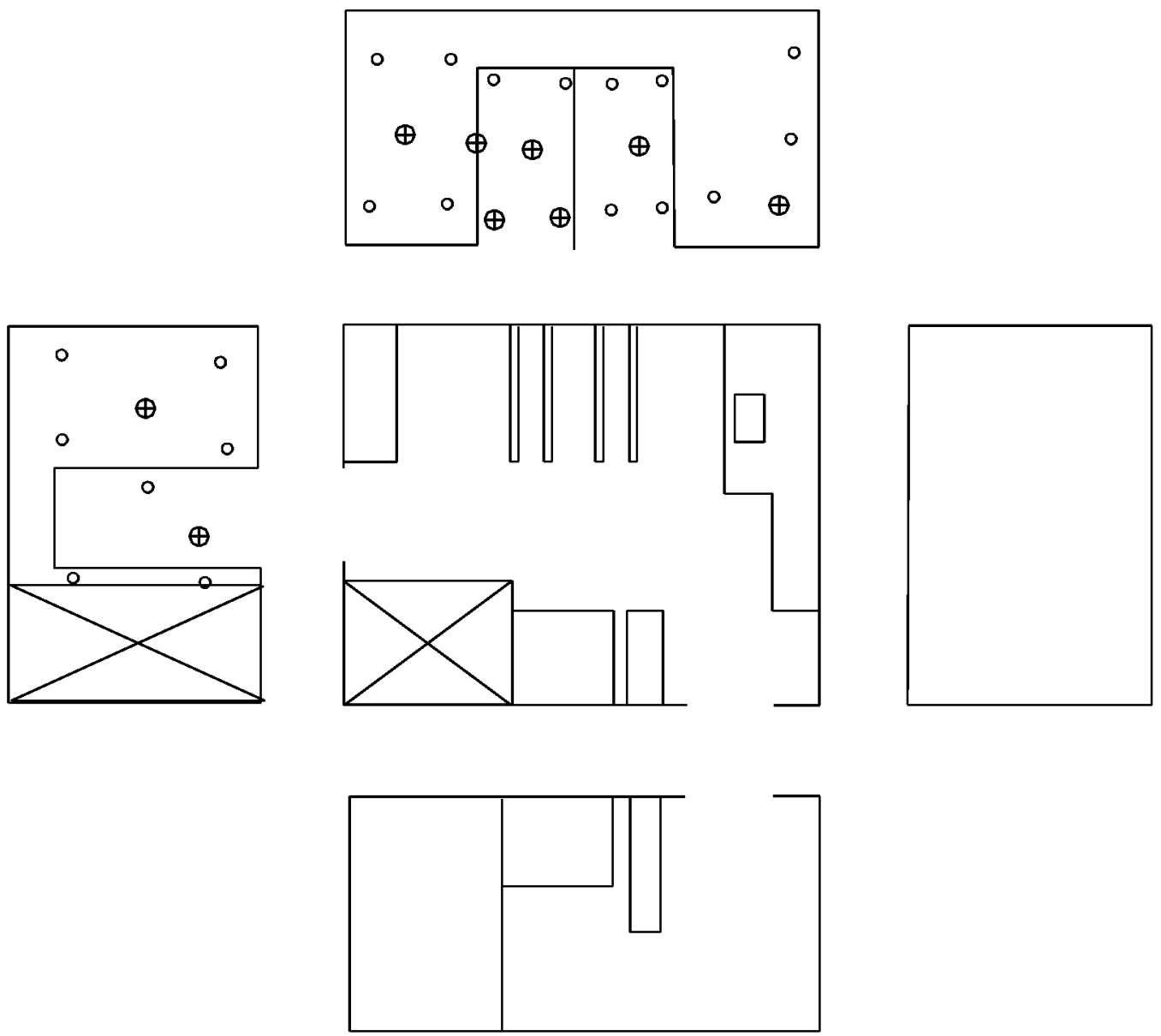

MEASUREMENT/SAMPLING LOCATIONS

- SINGLE-POINT

$\oplus$ SINGLE POINT AND SMEAR

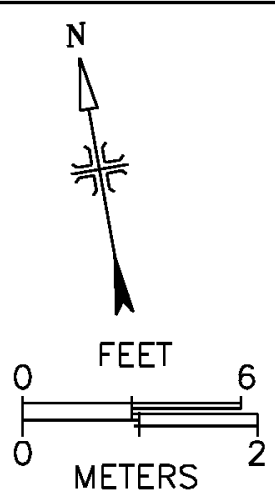

FIGURE 5: Source Vault Area, A107 - Lower Wall Measurement and Sampling Locations 

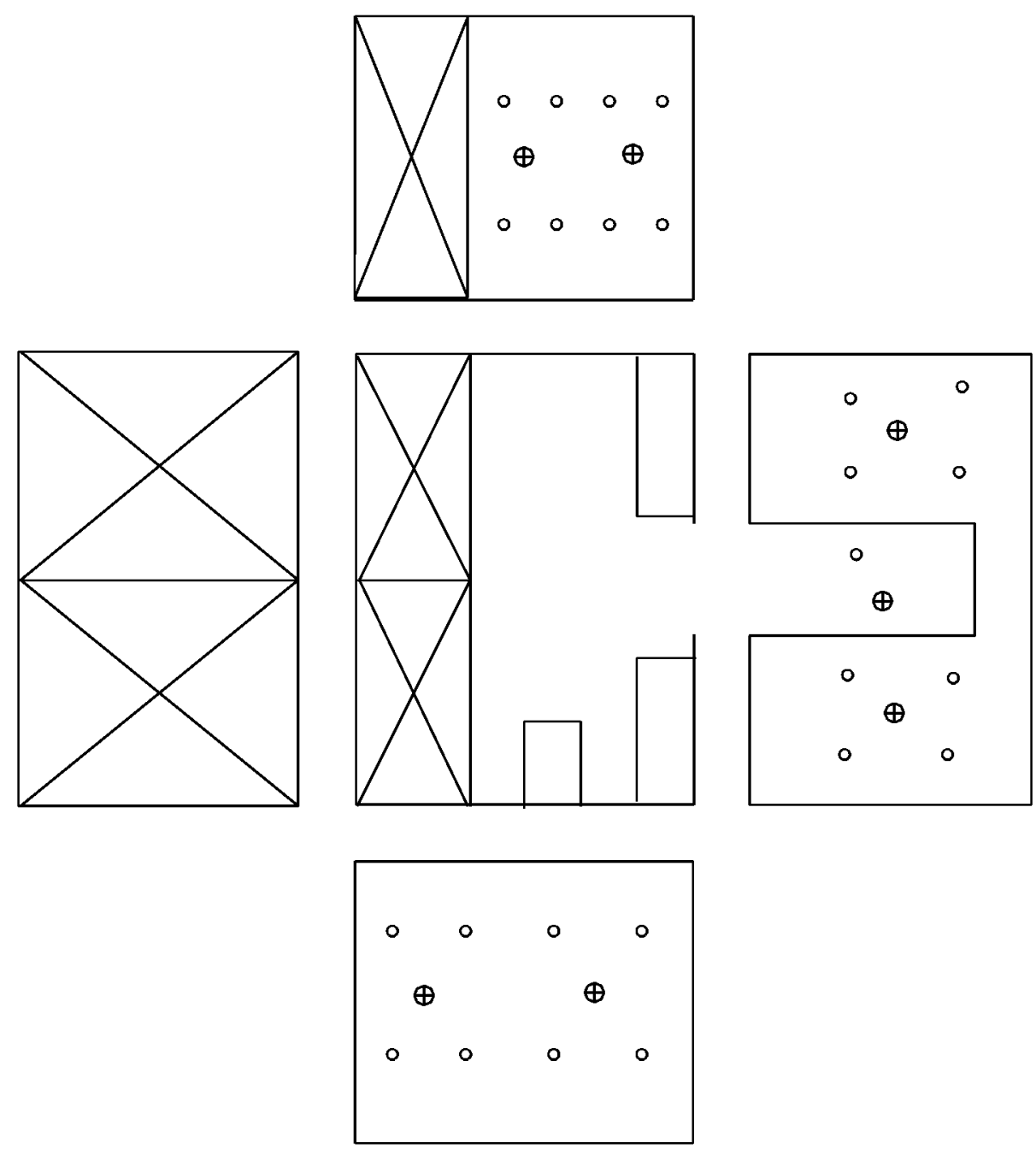

MEASUREMENT/SAMPLING LOCATIONS

- SINGLE-POINT

$\oplus$ SINGLE POINT AND SMEAR
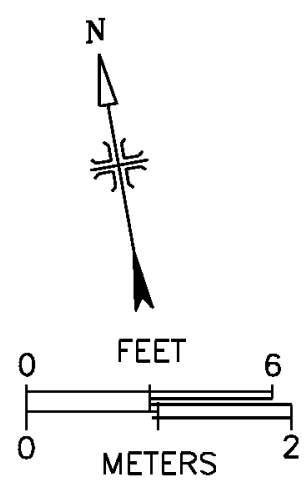

FIGURE 6: Source Vault Area, A107a - Lower Wall Measurement and Sampling Locations 
TABLES 
TABLE 1

SUMM ARY OF SURFACE ACTIVITY LEVELS

VANCE ROAD FACILITY SOURCE VAULT

OAK RIDGE INSTITUTE FOR SCIENCE AND EDUCATION

OAK RIDGE, TENNESSEE

\begin{tabular}{|c|c|c|c|c|c|c|c|}
\hline \multirow{2}{*}{ Location $^{\mathrm{a}}$} & \multicolumn{2}{|c|}{ Total Surface Activity $\left(\mathrm{dpm} / 100 \mathrm{~cm}^{2}\right)$} & \multicolumn{5}{|c|}{ Removable Activity (dpm/100 $\mathrm{cm}^{2}$ ) } \\
\hline & Alpha & Beta & Alpha & Beta & $\mathbf{H}-\mathbf{3}$ & C-14 & Sr-90 \\
\hline \multicolumn{8}{|l|}{ Cabinet \#1 } \\
\hline Top Shelf & 0 & 83 & 0 & -3 & $-^{\mathrm{b}}$ & -- & -- \\
\hline Third Shelf & 0 & 63 & 0 & 1 & -- & -- & -- \\
\hline Second Shelf & 0 & 120 & 0 & 3 & $27 \pm 14^{c}$ & $-2.2 \pm 5.0$ & \\
\hline Bottom Shelf & 0 & 170 & 0 & -1 & -- & -- & -- \\
\hline Underneath second shelf & 0 & 210 & 0 & -1 & -- & -- & -- \\
\hline Underneath bottom shelf & 8 & 1,300 & 0 & 96 & $45 \pm 15$ & $305 \pm 12$ & \\
\hline Cabinet Door & 8 & -89 & 0 & -3 & -- & -- & -- \\
\hline Right Side & 0 & -130 & 0 & 16 & $23 \pm 13$ & $-2.2 \pm 5.0$ & -- \\
\hline Glass Door & 8 & 130 & 0 & 4 & $20 \pm 13$ & $-4.6 \pm 4.9$ & -- \\
\hline \multicolumn{8}{|l|}{ Cabinet \# 2} \\
\hline Bottom Shelf & 8 & 130 & 2 & -2 & -- & -- & -- \\
\hline Middle Shelf & 0 & -7 & 0 & 8 & $12 \pm 13$ & $-2.5 \pm 5.0$ & -- \\
\hline Top Shelf & 0 & 150 & 2 & -3 & -- & - & -- \\
\hline Underside & -8 & 60 & 0 & 1 & $20 \pm 13$ & $-6.0 \pm 4.8$ & -- \\
\hline Door & 16 & -93 & 0 & -2 & $32 \pm 14$ & $2.5 \pm 5.2$ & -- \\
\hline
\end{tabular}


TABLE 1 (Continued)

SUMM ARY OF SURFACE ACTIVITY LEVELS

VANCE ROAD FACILITY SOURCE VAULT

OAK RIDGE INSTITUTE FOR SCIENCE AND EDUCATION

OAK RIDGE, TENNESSEE

\begin{tabular}{|c|c|c|c|c|c|c|c|}
\hline \multirow{2}{*}{ Location $^{2}$} & \multicolumn{2}{|c|}{ Total Surface Activity $\left(\mathrm{dpm} / 100 \mathrm{~cm}^{2}\right)$} & \multicolumn{5}{|c|}{ Removable Activity $\left(\mathrm{dpm} / 100 \mathrm{~cm}^{2}\right)$} \\
\hline & Alpha & Beta & Alpha & Beta & $\mathbf{H}-3$ & C-14 & Sr-90 \\
\hline \multicolumn{8}{|l|}{ Cabinet \# 3} \\
\hline Bottom Shelf & 0 & 0 & 0 & 2 & $14 \pm 13$ & $9.7 \pm 5.4$ & -- \\
\hline Middle Shelf & 16 & 230 & 2 & 4 & -- & -- & -- \\
\hline Door & 16 & -56 & 0 & -4 & -- & -- & -- \\
\hline \multicolumn{8}{|l|}{ Cabinet \#4 } \\
\hline Bottom Shelf & 0 & 170 & 0 & -3 & $5.2 \pm 12.5$ & $0.5 \pm 5.1$ & -- \\
\hline Second Shelf & 0 & 110 & 0 & -1 & -- & -- & -- \\
\hline Door & 16 & -13 & 0 & 2 & - & -- & -- \\
\hline \multicolumn{8}{|l|}{ Cabinet \# 5} \\
\hline Third Shelf & 0 & -76 & 0 & 1 & - & -- & -- \\
\hline Second Shelf & 8 & 23 & 0 & -2 & -- & -- & -- \\
\hline Underside & 0 & -33 & 0 & 1 & $23 \pm 13$ & $1.6 \pm 5.1$ & - \\
\hline \multicolumn{8}{|l|}{ Cabinet \# 6} \\
\hline Bottom Shelf & 0 & 220 & 2 & 6 & $18 \pm 13$ & $6.9 \pm 5.3$ & - \\
\hline Top Shelf & 24 & 83 & 2 & -2 & -- & - & -- \\
\hline Door & 8 & -43 & 0 & 1 & -- & -- & -- \\
\hline
\end{tabular}


TABLE 1 (Continued)

SUMM ARY OF SURFACE ACTIVITY LEVELS

VANCE ROAD FAC ILITY SOURCE VAULT

OAK RIDGE INSTITUTE FOR SCIENCE AND EDUCATION

OAK RIDGE, TENNESSEE

\begin{tabular}{|c|c|c|c|c|c|c|c|}
\hline \multirow{2}{*}{ Location $^{a}$} & \multicolumn{2}{|c|}{ Total Surface Activity $\left(\mathrm{dpm} / 100 \mathrm{~cm}^{2}\right)$} & \multicolumn{5}{|c|}{ Removable Activity $\left(\mathrm{dpm} / 100 \mathrm{~cm}^{2}\right)$} \\
\hline & Alpha & Beta & Alpha & Beta & H-3 & C-14 & Sr-90 \\
\hline \multicolumn{8}{|l|}{ Counter \# 1} \\
\hline Top & 0 & 530 & 0 & 3 & $38 \pm 14$ & $21.3 \pm 5.5$ & -- \\
\hline Left Drawer \#1 & -8 & -50 & 0 & 1 & - & -- & -- \\
\hline Left Drawer $\# 2$ & -8 & 99 & 2 & -2 & - & -- & -- \\
\hline Left Drawer $\# 3$ & 16 & 160 & 0 & -2 & - & -- & -- \\
\hline Left Drawer \#4 & 0 & 210 & 0 & -2 & - & -- & -- \\
\hline Right Drawer \#1 & 16 & 240 & 0 & 2 & - & -- & -- \\
\hline Right Drawer \#2 & 24 & 220 & 2 & 2 & - & -- & -- \\
\hline Right Drawer \#3 & 16 & 150 & 0 & -3 & - & -- & -- \\
\hline Right Drawer \#4 & 0 & 46 & 2 & 1 & - & -- & -- \\
\hline Top & 40 & 150 & 0 & 5 & - & -- & -- \\
\hline Top & 8 & -10 & 0 & 6 & - & -- & -- \\
\hline Side & 24 & -83 & 0 & 2 & $28 \pm 13$ & $4.2 \pm 4.9$ & -- \\
\hline \multicolumn{8}{|l|}{ Refrigerator } \\
\hline Interior & 8 & 780 & 3 & 34 & $161 \pm 19$ & $272 \pm 11$ & \\
\hline Exterior & 16 & 30 & 0 & -4 & $40 \pm 14$ & $6.2 \pm 5.0$ & \\
\hline
\end{tabular}


TABLE 1 (Continued)

SUMM ARY OF SURFACE ACTIVITY LEVELS

VANCE ROAD FAC ILITY SOURCE VAULT

OAK RIDGE INSTITUTE FOR SCIENCE AND EDUCATION

OAK RIDGE, TENNESSEE

\begin{tabular}{|c|c|c|c|c|c|c|c|}
\hline \multirow{2}{*}{ Location $^{a}$} & \multicolumn{2}{|c|}{ Total Surface Activity (dpm/100 $\mathrm{cm}^{2}$ ) } & \multicolumn{5}{|c|}{ Removable Activity $\left(\mathrm{dpm} / 100 \mathrm{~cm}^{2}\right)$} \\
\hline & Alpha & Beta & Alpha & Beta & $\mathrm{H}-3$ & C-14 & Sr-90 \\
\hline \multicolumn{8}{|l|}{ Desk } \\
\hline Top & 16 & 76 & 0 & 5 & $33 \pm 14$ & $10.1 \pm 5.1$ & -- \\
\hline Top & -8 & 50 & 0 & -1 & -- & -- & -- \\
\hline Top & 16 & 160 & 2 & 2 & -- & -- & -- \\
\hline Left Drawer & 8 & 180 & 0 & 2 & -- & -- & -- \\
\hline Right Drawer \#1 & 8 & 93 & 0 & -2 & -- & -- & -- \\
\hline Right Drawer \#2 & 24 & 40 & 3 & -1 & -- & -- & -- \\
\hline Right Drawer \#3 & 0 & 110 & 0 & 3 & -- & -- & -- \\
\hline Front & 0 & -73 & 0 & 1 & $31 \pm 14$ & $4.7 \pm 4.9$ & -- \\
\hline \multicolumn{8}{|l|}{ Cabinet \#2 } \\
\hline Bottom Right Cabinet & 16 & 240 & 0 & 3 & -- & -- & -- \\
\hline Center Right Cabinet & 0 & 110 & 2 & 4 & -- & -- & -- \\
\hline Center Left Cabinet & 8 & 99 & 0 & 4 & -- & -- & -- \\
\hline Bottom Left Cabinet & 24 & 160 & 0 & -3 & -- & -- & -- \\
\hline Top & 24 & 200 & 0 & 1 & $22 \pm 13$ & $5.3 \pm 4.9$ & -- \\
\hline Top Ledge & -8 & 100 & 0 & 2 & $19 \pm 13$ & $9.0 \pm 5.1$ & -- \\
\hline
\end{tabular}


TABLE 1 (Continued)

SUMM ARY OF SURFACE ACTIVITY LEVELS

VANCE ROAD FAC ILITY SOURCE VAULT

OAK RIDGE INSTITUTE FOR SCIENCE AND EDUCATION

OAK RIDGE, TENNESSEE

\begin{tabular}{|c|c|c|c|c|c|c|c|}
\hline \multirow{2}{*}{ Location $^{\mathbf{a}}$} & \multicolumn{2}{|c|}{ Total Surface Activity (dpm/100 $\left.\mathrm{cm}^{2}\right)$} & \multicolumn{5}{|c|}{ Removable Activity $\left(\mathrm{dpm} / 100 \mathrm{~cm}^{2}\right)$} \\
\hline & Alpha & Beta & Alpha & Beta & H-3 & C-14 & Sr-90 \\
\hline \multicolumn{8}{|l|}{ Cabinet \# 2 (continued) } \\
\hline Sink & 16 & 160 & 0 & -4 & $13 \pm 13$ & $2.3 \pm 4.8$ & -- \\
\hline Top Ledge & 8 & 160 & 0 & 6 & -- & -- & -- \\
\hline Top & 8 & 110 & 2 & 1 & -- & -- & -- \\
\hline Right Drawer & 0 & 180 & 0 & 1 & -- & -- & -- \\
\hline Left Drawer & 24 & 330 & 0 & 1 & -- & -- & -- \\
\hline Front Left & -8 & -83 & 0 & 3 & $11 \pm 12$ & $3.6 \pm 4.9$ & -- \\
\hline Front Right & 32 & -26 & 0 & -4 & -- & -- & -- \\
\hline \multicolumn{8}{|l|}{ File Cabinet } \\
\hline Top Drawer & -8 & 110 & 3 & 1 & -- & -- & -- \\
\hline Second Drawer & 0 & 170 & 2 & -5 & -- & -- & -- \\
\hline Third Drawer & -8 & 110 & 0 & -5 & -- & -- & -- \\
\hline Bottom Drawer & 16 & 50 & 2 & 3 & -- & -- & -- \\
\hline Top & 0 & 73 & 0 & 6 & $22 \pm 13$ & $5.6 \pm 4.9$ & -- \\
\hline
\end{tabular}


TABLE 1 (Continued)

SUMM ARY OF SURFACE ACTIVITY LEVELS

VANCE ROAD FAC ILITY SOURCE VAULT

OAK RIDGE INSTITUTE FOR SCIENCE AND EDUCATION

OAK RIDGE, TENNESSEE

\begin{tabular}{|c|c|c|c|c|c|c|c|}
\hline \multirow{2}{*}{ Location $^{\mathrm{a}}$} & \multicolumn{2}{|c|}{ Total Surface Activity $\left(\mathrm{dpm} / 100 \mathrm{~cm}^{2}\right)$} & \multicolumn{5}{|c|}{ Removable Activity $\left(\mathrm{dpm} / 100 \mathrm{~cm}^{2}\right)$} \\
\hline & Alpha & Beta & Alpha & Beta & $\mathbf{H}-\mathbf{3}$ & C-14 & Sr-90 \\
\hline \multicolumn{8}{|l|}{ File Cabinet (continued) } \\
\hline Left Side & 32 & -50 & 0 & -1 & $26 \pm 13$ & $-0.2 \pm 4.7$ & -- \\
\hline Cabinet \#2 - Top & 8 & 930 & 0 & -2 & -- & -- & $153 \pm 13$ \\
\hline Valance Piece & -8 & 280 & 0 & -1 & -- & -- & $3.3 \pm 8.1$ \\
\hline Refrigerator Top & 8 & 3,600 & 0 & 69 & -- & -- & $258 \pm 16$ \\
\hline $\begin{array}{c}\text { Cabinet Over Fridge - } \\
\text { Top }\end{array}$ & -8 & 11,000 & 0 & 299 & -- & -- & $1,863 \pm 38$ \\
\hline $\begin{array}{l}\text { Cabinet \#1 Post } \\
\text { Smear of Location }\end{array}$ & -- & 450 & 2 & -- & -- & -- & -- \\
\hline \multicolumn{8}{|l|}{ Counter \# 1} \\
\hline Top & 0 & 73 & 0 & 3 & $34 \pm 15$ & $16.4 \pm 5.7$ & -- \\
\hline Top & 0 & 96 & 0 & -2 & -- & - & -- \\
\hline $\begin{array}{l}\text { Top Right Drawer } \\
\text { Interior }\end{array}$ & 8 & 63 & 2 & -3 & -- & -- & -- \\
\hline $\begin{array}{l}\text { Top Middle Right } \\
\text { Drawer Interior }\end{array}$ & 0 & 140 & 0 & -3 & -- & -- & -- \\
\hline
\end{tabular}


TABLE 1 (Continued)

SUMM ARY OF SURFACE ACTIVITY LEVELS

VANCE ROAD FAC ILITY SOURCE VAULT

OAK RIDGE INSTITUTE FOR SCIENCE AND EDUCATION

OAK RIDGE, TENNESSEE

\begin{tabular}{|c|c|c|c|c|c|c|c|}
\hline \multirow{2}{*}{ Location $^{\mathbf{a}}$} & \multicolumn{2}{|c|}{ Total Surface Activity $\left(\mathrm{dpm} / 100 \mathrm{~cm}^{2}\right)$} & \multicolumn{5}{|c|}{ Removable Activity $\left(\mathrm{dpm} / 100 \mathrm{~cm}^{2}\right)$} \\
\hline & Alpha & Beta & Alpha & Beta & $\mathbf{H - 3}$ & $\mathrm{C}-14$ & Sr-90 \\
\hline \multicolumn{8}{|l|}{ Counter \# 1 (continued) } \\
\hline $\begin{array}{l}\text { Top Middle Left } \\
\text { Drawer Interior }\end{array}$ & 0 & 63 & 2 & 5 & -- & -- & -- \\
\hline $\begin{array}{l}\text { Top Left Drawer } \\
\text { Interior }\end{array}$ & 0 & 180 & 0 & -3 & -- & -- & -- \\
\hline $\begin{array}{l}\text { Top Middle Left } \\
\text { Drawer Interior }\end{array}$ & 8 & 60 & 0 & 2 & -- & -- & -- \\
\hline $\begin{array}{l}\text { Top Middle Right } \\
\text { Drawer Interior }\end{array}$ & 0 & 23 & 0 & -2 & -- & -- & -- \\
\hline $\begin{array}{l}\text { Middle Middle Right } \\
\text { Drawer Right Drawer } \\
\text { Interior }\end{array}$ & 8 & 73 & 0 & -4 & -- & -- & -- \\
\hline $\begin{array}{l}\text { Middle Middle Left } \\
\text { Drawer Interior }\end{array}$ & 8 & 69 & 0 & 5 & -- & -- & -- \\
\hline $\begin{array}{l}\text { Bottom Drawer } \\
\text { Interior }\end{array}$ & -8 & 66 & 0 & -3 & $20 \pm 15$ & $-2.3 \pm 5.0$ & -- \\
\hline Front Exterior & 8 & -43 & 0 & 2 & $3.5 \pm 13.6$ & $1.9 \pm 5.2$ & -- \\
\hline Left Side Exterior & 24 & -40 & 0 & 6 & $4.9 \pm 13.7$ & $-3.1 \pm 5.0$ & -- \\
\hline
\end{tabular}


TABLE 1 (Continued)

SUMM ARY OF SURFACE ACTIVITY LEVELS

VANCE ROAD FAC ILITY SOURCE VAULT

OAK RIDGE INSTITUTE FOR SCIENCE AND EDUCATION

OAK RIDGE, TENNESSEE

\begin{tabular}{|c|c|c|c|c|c|c|c|}
\hline \multirow{2}{*}{ Location $^{2}$} & \multicolumn{2}{|c|}{ Total Surface Activity $\left(\mathrm{dpm} / 100 \mathrm{~cm}^{2}\right)$} & \multicolumn{5}{|c|}{ Removable Activity $\left(\mathrm{dpm} / 100 \mathrm{~cm}^{2}\right)$} \\
\hline & Alpha & Beta & Alpha & Beta & $\mathbf{H}-3$ & C-14 & Sr-90 \\
\hline \multicolumn{8}{|l|}{ Counter \# 2} \\
\hline Top & 0 & 99 & 0 & 2 & $9.3 \pm 14.0$ & $-0.7 \pm 5.1$ & -- \\
\hline Top Drawer Interior & 0 & 160 & 0 & 24 & -- & -- & -- \\
\hline $\begin{array}{l}\text { Second Drawer } \\
\text { Interior }\end{array}$ & 0 & 130 & 0 & 0 & -- & -- & -- \\
\hline Third Drawer Interior & -8 & 96 & 0 & 0 & -- & -- & -- \\
\hline $\begin{array}{l}\text { Fourth Drawer } \\
\text { Interior }\end{array}$ & 8 & 73 & 0 & 2 & $2.0 \pm 13.6$ & $-2.5 \pm 5.0$ & -- \\
\hline $\begin{array}{l}\text { Bottom Drawer } \\
\text { Interior }\end{array}$ & 0 & 56 & 2 & 3 & -- & -- & -- \\
\hline Front & 16 & -56 & 0 & 0 & $0.8 \pm 13.5$ & $0.0 \pm 5.1$ & -- \\
\hline Left Side & 0 & -180 & 0 & -3 & -- & -- & -- \\
\hline Right Side & 0 & -86 & 2 & 2 & -- & -- & -- \\
\hline \multicolumn{8}{|l|}{ Counter \# 3} \\
\hline Underneath Right & 0 & 170 & 0 & 0 & $-6.5 \pm 13.1$ & $-3.8 \pm 5.0$ & -- \\
\hline Underneath Left & 0 & 110 & 0 & -3 & -- & -- & -- \\
\hline Top Right & 0 & 93 & 2 & 5 & $16 \pm 14$ & $5.6 \pm 5.3$ & -- \\
\hline Sink & 0 & 96 & 0 & 2 & $17 \pm 14$ & $4.6 \pm 5.3$ & -- \\
\hline
\end{tabular}


TABLE 1 (Continued)

SUMM ARY OF SURFACE ACTIVITY LEVELS

VANCE ROAD FAC ILITY SOURCE VAULT

OAK RIDGE INSTITUTE FOR SCIENCE AND EDUCATION

OAK RIDGE, TENNESSEE

\begin{tabular}{|c|c|c|c|c|c|c|c|}
\hline \multirow{2}{*}{ Location $^{a}$} & \multicolumn{2}{|c|}{ Total Surface Activity $\left(\mathrm{dpm} / 100 \mathrm{~cm}^{2}\right)$} & \multicolumn{5}{|c|}{ Removable Activity $\left(\mathrm{dpm} / 100 \mathrm{~cm}^{2}\right)$} \\
\hline & Alpha & Beta & Alpha & Beta & H-3 & C-14 & Sr-90 \\
\hline \multicolumn{8}{|l|}{ Cabinet \#3 (continued) } \\
\hline Top Left & 0 & 130 & 0 & 0 & -- & -- & -- \\
\hline Front Left & 0 & -110 & 0 & 8 & $-1.9 \pm 13.4$ & $-3.9 \pm 5.0$ & -- \\
\hline Front Right & 8 & -7 & 0 & 3 & -- & -- & -- \\
\hline Right Side & 0 & -60 & 0 & 1 & -- & -- & -- \\
\hline \multicolumn{8}{|l|}{ Cabinet } \\
\hline Underside Front Edge & -8 & 1,300 & 0 & 5 & $8.8 \pm 13.9$ & $-6.3 \pm 4.9$ & -- \\
\hline Bottom Shelf & 8 & -26 & 0 & -3 & $7.4 \pm 13.9$ & $0.9 \pm 5.2$ & -- \\
\hline Second Shelf & 8 & 120 & 0 & 6 & -- & -- & -- \\
\hline Third Shelf & 8 & 89 & 0 & 4 & - & -- & -- \\
\hline Top Shelf & 0 & 120 & 0 & -4 & -- & -- & -- \\
\hline Door & 8 & 96 & 2 & 4 & $1.2 \pm 13.5$ & $-0.8 \pm 5.1$ & -- \\
\hline Right Side & 8 & -76 & 0 & -2 & $8.9 \pm 14.0$ & $-2.2 \pm 5.0$ & -- \\
\hline \multicolumn{8}{|l|}{ Room 107A South Wall } \\
\hline 1 & 8 & 20 & -- & -- & -- & -- & -- \\
\hline 2 & 8 & -43 & -- & -- & -- & -- & -- \\
\hline
\end{tabular}


TABLE 1 (Continued)

SUMM ARY OF SURFACE ACTIVITY LEVELS

VANCE ROAD FAC ILITY SOURCE VAULT

OAK RIDGE INSTITUTE FOR SCIENCE AND EDUCATION

OAK RIDGE, TENNESSEE

\begin{tabular}{|c|c|c|c|c|c|c|c|}
\hline \multirow{2}{*}{ Location $^{\mathrm{a}}$} & \multicolumn{2}{|c|}{ Total Surface Activity $\left(\mathrm{dpm} / 100 \mathrm{~cm}^{2}\right)$} & \multicolumn{5}{|c|}{ Removable Activity (dpm/100 $\mathrm{cm}^{2}$ ) } \\
\hline & Alpha & Beta & Alpha & Beta & H-3 & C-14 & Sr-90 \\
\hline \multicolumn{8}{|c|}{ Room 107A - South Wall (continued) } \\
\hline 3 & -8 & 33 & -- & -- & -- & -- & -- \\
\hline 4 & -8 & -7 & -- & -- & -- & -- & -- \\
\hline 5 & 8 & 17 & -- & -- & $-1.0 \pm 12.9$ & $-5.5 \pm 5.2$ & \\
\hline 6 & 0 & 33 & - & -- & -- & -- & -- \\
\hline 7 & 0 & 7 & -- & -- & -- & -- & -- \\
\hline 8 & 0 & -46 & -- & & & & \\
\hline 9 & -8 & -30 & -- & -- & -- & -- & -- \\
\hline 10 & -8 & 33 & -- & -- & $-2.8 \pm 12.8$ & $-4.2 \pm 5.0$ & -- \\
\hline \multicolumn{8}{|c|}{ Room 107A - East Wall } \\
\hline 11 & 8 & 20 & -- & -- & -- & -- & -- \\
\hline 12 & 8 & 17 & -- & -- & -- & -- & -- \\
\hline 13 & -8 & -23 & -- & -- & -- & -- & -- \\
\hline 14 & 0 & -36 & -- & -- & -- & -- & -- \\
\hline 15 & -8 & -110 & -- & -- & $17.2 \pm 13.9$ & $-5.3 \pm 5.2$ & -- \\
\hline 16 & 8 & 60 & -- & -- & -- & -- & -- \\
\hline
\end{tabular}


TABLE 1 (Continued)

SUMM ARY OF SURFACE ACTIVITY LEVELS

VANCE ROAD FACILITY SOURCE VAULT

OAK RIDGE INSTITUTE FOR SCIENCE AND EDUCATION

OAK RIDGE, TENNESSEE

\begin{tabular}{|c|c|c|c|c|c|c|c|}
\hline \multirow{2}{*}{ Location $^{\mathrm{a}}$} & \multicolumn{2}{|c|}{ Total Surface Activity $\left(\mathrm{dpm} / 100 \mathrm{~cm}^{2}\right)$} & \multicolumn{5}{|c|}{ Removable Activity $\left(\mathrm{dpm} / 100 \mathrm{~cm}^{2}\right)$} \\
\hline & Alpha & Beta & Alpha & Beta & H-3 & C-14 & Sr-90 \\
\hline \multicolumn{8}{|c|}{ Room 107A - East Wall (continued) } \\
\hline 17 & 0 & 10 & -- & -- & $8.4 \pm 13.5$ & $-3.6 \pm 5.2$ & -- \\
\hline 18 & 0 & -89 & -- & -- & -- & -- & -- \\
\hline 19 & 24 & 0 & -- & -- & -- & -- & -- \\
\hline 20 & 8 & 7 & -- & -- & -- & -- & -- \\
\hline 21 & -8 & -150 & -- & -- & -- & -- & -- \\
\hline 22 & 8 & -96 & -- & -- & $3.4 \pm 13.2$ & $-6.0 \pm 5.1$ & -- \\
\hline \multicolumn{8}{|c|}{ Room 107A - North Wall } \\
\hline 23 & 8 & 0 & -- & -- & -- & -- & -- \\
\hline 24 & 0 & 36 & -- & -- & -- & -- & -- \\
\hline 25 & 8 & -73 & -- & -- & -- & -- & -- \\
\hline 26 & 24 & -43 & -- & -- & -- & -- & -- \\
\hline 27 & 8 & -150 & -- & -- & $-2.1 \pm 12.9$ & $6.0 \pm 5.1$ & -- \\
\hline 28 & -8 & -130 & -- & -- & -- & -- & -- \\
\hline 29 & 0 & -20 & -- & -- & -- & -- & -- \\
\hline 30 & 8 & -13 & -- & -- & -- & -- & -- \\
\hline
\end{tabular}


TABLE 1 (Continued)

SUMM ARY OF SURFACE ACTIVITY LEVELS

VANCE ROAD FACILITY SOURCE VAULT

OAK RIDGE INSTITUTE FOR SCIENCE AND EDUCATION

OAK RIDGE, TENNESSEE

\begin{tabular}{|c|c|c|c|c|c|c|c|}
\hline \multirow{2}{*}{ Location $^{\mathrm{a}}$} & \multicolumn{2}{|c|}{ Total Surface Activity $\left(\mathrm{dpm} / 100 \mathrm{~cm}^{2}\right)$} & \multicolumn{5}{|c|}{ Removable Activity $\left(\mathrm{dpm} / 100 \mathrm{~cm}^{2}\right)$} \\
\hline & Alpha & Beta & Alpha & Beta & H-3 & C-14 & Sr-90 \\
\hline \multicolumn{8}{|c|}{ Room 107A - North Wall (continued) } \\
\hline 31 & 24 & -23 & -- & -- & -- & -- & -- \\
\hline 32 & -8 & -36 & -- & -- & $7.4 \pm 13.3$ & $-2.2 \pm 5.3$ & -- \\
\hline \multicolumn{8}{|c|}{ Room A107 - West Wall } \\
\hline 1 & 24 & -60 & -- & -- & -- & -- & -- \\
\hline 2 & -8 & -53 & -- & -- & -- & -- & -- \\
\hline 3 - Door & -8 & 370 & -- & -- & $6.6 \pm 13.4$ & $5.7 \pm 5.6$ & -- \\
\hline 4 - Door & -8 & 0 & -- & -- & -- & -- & -- \\
\hline 5 & 0 & 43 & -- & -- & -- & -- & -- \\
\hline 6 & 0 & -93 & -- & -- & -- & -- & -- \\
\hline 7 & 8 & -63 & -- & -- & -- & -- & -- \\
\hline 8 & 0 & -13 & -- & -- & -- & -- & -- \\
\hline 9 & 24 & -20 & -- & -- & $-1.0 \pm 12.9$ & $-2.4 \pm 5.3$ & -- \\
\hline \multicolumn{8}{|c|}{ Room A107 - North Wall } \\
\hline 10 & -8 & -73 & -- & -- & -- & -- & -- \\
\hline 11 & 0 & -76 & -- & -- & -- & -- & -- \\
\hline
\end{tabular}


TABLE 1 (Continued)

SUMM ARY OF SURFACE ACTIVITY LEVELS

VANCE ROAD FACILITY SOURCE VAULT

OAK RIDGE INSTITUTE FOR SCIENCE AND EDUCATION

OAK RIDGE, TENNESSEE

\begin{tabular}{|c|c|c|c|c|c|c|c|}
\hline \multirow{2}{*}{ Location $^{a}$} & \multicolumn{2}{|c|}{ Total Surface Activity $\left(\mathrm{dpm} / 100 \mathrm{~cm}^{2}\right)$} & \multicolumn{5}{|c|}{ Removable Activity $\left(\mathrm{dpm} / 100 \mathrm{~cm}^{2}\right)$} \\
\hline & Alpha & Beta & Alpha & Beta & $\mathbf{H}-3$ & $\mathrm{C}-14$ & Sr-90 \\
\hline \multicolumn{8}{|c|}{ Room A107 - North Wall (continued) } \\
\hline 12 & 8 & 420 & -- & -- & -- & -- & -- \\
\hline 13 & -8 & -46 & -- & -- & -- & -- & -- \\
\hline 14 & 0 & -96 & & & $-1.8 \pm 12.9$ & $-7.1 \pm 5.1$ & -- \\
\hline 15 & 8 & 1,900 & 0 & -2 & $12.0 \pm 13.6$ & $-3.1 \pm 5.2$ & -- \\
\hline 16 & -8 & -89 & -- & -- & -- & -- & -- \\
\hline 17 & 8 & -130 & -- & -- & -- & -- & -- \\
\hline 18 & 0 & 790 & 0 & 6 & -- & -- & -- \\
\hline 19 & -8 & 710 & 0 & -3 & -- & -- & -- \\
\hline 20 & -8 & 10 & -- & -- & $1.2 \pm 13.1$ & $-8.7 \pm 5.0$ & -- \\
\hline 21 & 16 & -110 & -- & -- & -- & -- & -- \\
\hline 22 & -8 & -140 & -- & -- & -- & -- & -- \\
\hline 23 & -8 & 330 & -- & -- & -- & -- & -- \\
\hline 24 & 0 & 820 & -- & -- & -- & -- & -- \\
\hline 25 & 0 & -120 & -- & -- & $0.4 \pm 13.0$ & $-5.2 \pm 5.2$ & -- \\
\hline
\end{tabular}


TABLE 1 (Continued)

SUMM ARY OF SURFACE ACTIVITY LEVELS

VANCE ROAD FAC ILITY SOURCE VAULT

OAK RIDGE INSTITUTE FOR SCIENCE AND EDUCATION

OAK RIDGE, TENNESSEE

\begin{tabular}{|c|c|c|c|c|c|c|c|}
\hline \multirow{2}{*}{ Location $^{\mathrm{a}}$} & \multicolumn{2}{|c|}{ Total Surface Activity $\left(\mathrm{dpm} / 100 \mathrm{~cm}^{2}\right)$} & \multicolumn{5}{|c|}{ Removable Activity $\left(\mathrm{dpm} / 100 \mathrm{~cm}^{2}\right)$} \\
\hline & Alpha & Beta & Alpha & Beta & H-3 & $\mathrm{C}-14$ & Sr-90 \\
\hline \multicolumn{8}{|c|}{ Room A107 - North Wall (continued) } \\
\hline 26 & 0 & -69 & -- & -- & -- & -- & -- \\
\hline 27 & -8 & 33 & -- & -- & -- & -- & -- \\
\hline 28 & -8 & -36 & -- & -- & $-0.4 \pm 13.0$ & $-3.7 \pm 5.2$ & -- \\
\hline 29 & 0 & 7 & -- & -- & -- & -- & -- \\
\hline \multicolumn{8}{|c|}{ Rooms A107 and A107A } \\
\hline Baseboard & 48 & 42,000 & 11 & 1,300 & $1,262 \pm 43$ & $2,505 \pm 32$ & $3,702 \pm 16$ \\
\hline Ceiling Tile (back) & 8 & 82,000 & 5 & 16 & $166 \pm 19$ & $330 \pm 12$ & $361 \pm 5.0$ \\
\hline Ceiling Tile (back) & 32 & 19,000 & 3 & 36 & $191 \pm 20$ & $364 \pm 13$ & $386 \pm 6.0$ \\
\hline Ceiling Tile (back) & -8 & 280,000 & 13 & 2,500 & $42,700 \pm 240$ & $81,770 \pm 180$ & $72,379 \pm 68$ \\
\hline Ceiling Tile (back) & 0 & 3,400 & 0 & 6 & $75 \pm 15$ & $32.4 \pm 6.1$ & $30.2 \pm 2.7$ \\
\hline Misc. Ceiling Grid & -8 & 110 & -- & -- & $14 \pm 12$ & $-1.5 \pm 4.9$ & -- \\
\hline Misc. Ceiling Grid & 0 & 130 & -- & -- & -- & -- & -- \\
\hline Ceiling Tile (back) & 16 & 96 & -- & -- & $1.8 \pm 11.3$ & $4.4 \pm 5.1$ & $-3.0 \pm 2.3$ \\
\hline Ceiling Tile (front) & 8 & 110 & -- & -- & -- & -- & -- \\
\hline Light Screen & 0 & 190 & -- & -- & $7.9 \pm 11.6$ & $2.5 \pm 5.0$ & $2.1 \pm 2.4$ \\
\hline
\end{tabular}


TABLE 1 (Continued)

SUMM ARY OF SURFACE ACTIVITY LEVELS

VANCE ROAD FAC ILITY SOURCE VAULT

OAK RIDGE INSTITUTE FOR SCIENCE AND EDUCATION

OAK RIDGE, TENNESSEE

\begin{tabular}{|c|c|c|c|c|c|c|c|}
\hline \multirow{2}{*}{ Location $^{\mathrm{a}}$} & \multicolumn{2}{|c|}{ Total Surface Activity (dpm/100 cm²) } & \multicolumn{5}{|c|}{ Removable Activity (dpm/100 $\mathrm{cm}^{2}$ ) } \\
\hline & Alpha & Beta & Alpha & Beta & $\mathbf{H}-3$ & $\mathrm{C}-14$ & Sr-90 \\
\hline \multicolumn{8}{|l|}{ Room $A 107$} \\
\hline Door Frame & -8 & 11,000 & 0 & 14 & $397 \pm 26$ & $669 \pm 17$ & $705.7 \pm 7.1$ \\
\hline Metal Rod & 0 & 4,300 & 0 & 110 & $85 \pm 16$ & $112.0 \pm 8.2$ & $109.1 \pm 3.5$ \\
\hline \multicolumn{8}{|l|}{ Hood Ductwork } \\
\hline Hood 2 Exit & 0 & 1,500 & 1 & 3 & $143 \pm 19$ & $58 \pm 7$ & $-2 \pm 2$ \\
\hline Hood 1 Exit & 0 & 7,000 & 0 & 38 & $419 \pm 27$ & $454 \pm 14$ & $13 \pm 2$ \\
\hline Hood 1 / Section 1 & 0 & 17,000 & 0 & 56 & $1,040 \pm 40$ & $1,059 \pm 21$ & $22 \pm 3$ \\
\hline Hood 1 / Section 2 & 16 & 10,000 & 0 & 45 & $493 \pm 29$ & $828 \pm 19$ & $48 \pm 3$ \\
\hline Hood 1 / Section 2 & 8 & 20,000 & 0 & 32 & $1,168 \pm 42$ & $1,451 \pm 25$ & $29 \pm 3$ \\
\hline Hood 1 - Stack & 8 & 320 & 2 & 1 & $-2 \pm 12$ & $26 \pm 6$ & $2 \pm 2$ \\
\hline Hood 2 / Section 1 & 40 & 1,000 & 0 & 5 & $108 \pm 17$ & $55 \pm 7$ & $-1 \pm 2$ \\
\hline Hood 2 / Section 2 & 16 & 6,900 & 0 & 240 & $935 \pm 38$ & $750 \pm 18$ & $11 \pm 2$ \\
\hline Hood 2 / Section 2 & 16 & 26,000 & 3 & 530 & $2,418 \pm 60$ & $2,551 \pm 32$ & $64 \pm 4$ \\
\hline Hood 2 / Section 3 & 48 & 2,000 & 0 & 6 & $205 \pm 21$ & $109 \pm 8$ & $-3 \pm 2$ \\
\hline Hood 2 / Section 3 & 32 & 1,600 & -- & -- & -- & -- & -- \\
\hline Hood 2 / Section 4 & 0 & 3,200 & 3 & 590 & $785 \pm 35$ & $544 \pm 16$ & $19 \pm 3$ \\
\hline
\end{tabular}


TABLE 1 (Continued)

SUMM ARY OF SURFACE ACTIVITY LEVELS

VANCE ROAD FAC ILITY SOURCE VAULT

OAK RIDGE INSTITUTE FOR SCIENCE AND EDUCATION

OAK RIDGE, TENNESSEE

\begin{tabular}{|c|c|c|c|c|c|c|c|}
\hline \multirow{2}{*}{ Location $^{a}$} & \multicolumn{2}{|c|}{ Total Surface Activity $\left(\mathrm{dpm} / 100 \mathrm{~cm}^{2}\right)$} & \multicolumn{5}{|c|}{ Removable Activity $\left(\mathrm{dpm} / 100 \mathrm{~cm}^{2}\right)$} \\
\hline & Alpha & Beta & Alpha & Beta & H-3 & C-14 & Sr-90 \\
\hline \multicolumn{8}{|c|}{ Hood Ductwork (continued) } \\
\hline Hood 2 / Section 4 & 8 & 5,100 & 5 & 120 & $87 \pm 16$ & $20 \pm 6$ & $-12 \pm 2$ \\
\hline Hood 2 / Section 5 & 16 & 19,000 & 0 & 120 & $1,635 \pm 50$ & $1,709 \pm 27$ & $67 \pm 4$ \\
\hline Hood $2 /$ Section 5 & 16 & 7,000 & 3 & 40 & $836 \pm 36$ & $678 \pm 17$ & $11 \pm 2$ \\
\hline Hood 2 / Section 6 & -8 & 3,800 & 3 & 200 & $515 \pm 30$ & $258 \pm 11$ & $-6 \pm 2$ \\
\hline Hood 2 / Section 6 & 24 & 25,000 & 3 & 380 & $3,476 \pm 71$ & $3,841 \pm 39$ & $70 \pm 4$ \\
\hline
\end{tabular}

${ }^{a}$ Refer to Figures 5 and 6.

b Sample not collected.

'Uncertainties are total propagated uncertainties at the $95 \%$ confidence level. 


\section{REFERENCES}

Oak Ridge Institute for Science and Education. Survey Procedures Manual for the Environmental Survey and Site Assessment Program, Revision 10. Oak Ridge, TN; January 7 , 1998.

Oak Ridge Institute for Science and Education. Proposed Radiological Assessment Survey Plan for the Vance Road Facility Source Vault, Oak Ridge Institute for Science and Education, Oak Ridge, Tennessee. Oak Ridge, TN; March 14, 2000a.

Oak Ridge Institute for Science and Education. Quality Assurance Manual for the Environmental Survey and Site Assessment Program, Revision 10. Oak Ridge, TN; March 10, $2000 \mathrm{~b}$.

Oak Ridge Institute for Science and Education. Laboratory Procedures Manual for the Environmental Survey and Site Assessment Program, Revision 15. Oak Ridge, TN; May 10, 2000c.

U. S. Department of Energy (DOE). "Radiation Protection of the Public and the Environment," DOE Order 5400.5, Washington, DC; February 8, 1990.

U. S. Department of Energy. DOE Memorandum from R. Pelletier to Distribution, "Application of DOE 5400.5 Requirements for Release and Control of Property Containing Residual Radioactive Material", November 17, 1995. 
APPENDIX A

MAJOR INSTRUMENTATION 


\section{APPENDIX A}

\section{MAJOR INSTRUMENTATION}

The display of a specific product is not to be construed as an endorsement of the product or its manufacturer by the author or his employer.

\section{Direct Radiation Measurement}

\section{Instruments}

Ludlum Ratemeter-Scaler

Model 2221

(Ludlum Measurements, Inc.,

Sweetwater, TX)

\section{$\underline{\text { Detectors }}$}

Ludlum Gas Proportional Detector

Model 43-68

Physical Probe Area, $126 \mathrm{~cm}^{2}$

(Ludlum Measurements, Inc.,

Sweetwater, TX)

\section{LABORATORY ANALYTICAL INSTRUMENTATION}

Low Background Gas Proportional Counter

Model LB-5100-W

(Oxford, Oak Ridge, TN)

Tri-Carb Liquid Scintillation Analyzer

Model 1900CA

(Packard Instrument Co., Meriden, CT) 
APPENDIX B

\section{SURVEY AND ANALYTICAL PROCEDURES}




\section{APPENDIX B}

\section{SURVEY AND ANALYTICAL PROCEDURES}

\section{Project Health and Safety}

All survey and laboratory activities were conducted in accordance with ORISE health and safety and radiation protection programs.

\section{Calibration and Quality Assurance}

Calibration of all field and laboratory instrumentation was based on standards/sources, traceable to NIST, when such standards/sources were available. In cases where they were not available, standards of an industry-recognized organization were used.

Analytical and field survey activities were conducted in accordance with procedures from the following documents of the Environmental Survey and Site Assessment Program:

- $\quad$ Survey Procedures Manual (January 1998)

- $\quad$ Laboratory Procedures Manual (May 2000)

- $\quad$ Quality Assurance Manual (March 2000)

The procedures contained in these manuals were developed to meet the requirements of DOE Order 414.1A and ASME NQA-1 for Quality Assurance and contain measures to assess processes during their performance.

Quality control procedures include:

- Daily instrument background and check-source measurements to confirm that equipment operation is within acceptable statistical fluctuations.

- Participation in MAPEP, NRIP, ITP, and EML Laboratory Quality Assurance Programs. 
- $\quad$ Training and certification of all individuals performing procedures.

- $\quad$ Periodic internal and external audits.

\section{UnCERTAinties AND Detection Limits}

The uncertainties associated with the analytical data presented in the tables of this report represent the total propagated uncertainty at the $95 \%$ confidence level for that data. These uncertainties were calculated based on both the gross sample count levels and the associated background count levels.

Detection limits, referred to as minimum detectable concentration (MDC), were based on 3 plus 4.65 times the standard deviation of the background count $[3+(4.65 \sqrt{\mathrm{BKG}})]$. When the activity was determined to be less than the MDC of the measurement procedure, the result was reported as the actual (positive or negative) value. Because of variations in background levels, measurement efficiencies, and contributions from other radionuclides in the vicinity of the measurement area, the detection limits may differ from measurement to measurement and instrument to instrument.

\section{Survey Procedures}

\section{Surface Scans}

Surface scans were performed by passing the detectors slowly over the surface; the distance between the detectors and the surface was maintained at a minimum - nominally about $1 \mathrm{~cm}$. Surfaces were scanned using small area $\left(126 \mathrm{~cm}^{2}\right)$ gas proportional hand-held detectors. Identification of elevated levels was based on increases in the audible signal from the recording and/or indicating instrument. Combinations of detectors and instruments used for the scans were:

Alpha $\quad$ - $\quad$ gas proportional detector with ratemeter-scaler

Alpha + Beta $\quad-\quad$ gas proportional detector with ratemeter-scaler 
Scan minimum detectable concentrations (MDCs) were estimated using the calculational approach described in NUREG-1507. ${ }^{1}$ The scan MDC is a function of many variables, including the background level. Typical beta background levels on floors and walls ranged from 250 to $450 \mathrm{cpm}$ for the hand-held gas proportional detectors. Additional parameters selected for the calculation of scan MDCs include a four-second observation interval, a specified level of performance at the first scanning stage of $95 \%$ true positive rate and $25 \%$ false positive rate, which yields a $d^{\prime}$ value of 2.32 (NUREG-1507, Table 6.1), and a surveyor efficiency of 0.5 . The instrument efficiencies for the hand-held gas proportional detectors calibrated to Th-230, Sr-90, and $\mathrm{C}$-14 were $0.10,0.24$, and 0.08 , respectively. To illustrate an example for the hand-held gas proportional detector, the minimum detectable count rate (MDCR) and scan MDC for beta activity can be calculated as follows:

$$
\begin{aligned}
& b_{i}=(250 \mathrm{cpm})(4 \mathrm{~s})(1 \mathrm{~min} / 60 \mathrm{~s})=16.7 \text { counts, } \\
& \operatorname{MDCR}=(2.32)(16.7 \mathrm{counts})^{1 / 2}[(60 \mathrm{~s} / \mathrm{min}) /(4 \mathrm{~s})]=142 \mathrm{cpm}, \\
& \operatorname{MDCR}_{\text {surveyor }}=142(0.5)^{1 / 2}=201 \mathrm{cpm}
\end{aligned}
$$

The scan MDC is calculated assuming a source efficiency of 0.50 (for $\mathrm{Sr}-90$ ):

$$
\text { Scan } M D C=\frac{M D C R_{\text {surveyor }}}{\left(\epsilon_{s}\right)\left(\epsilon_{i}\right)\left(\frac{\text { probe area }}{100 \mathrm{~cm}^{2}}\right)}=d p m / 100 \mathrm{~cm}^{2}
$$

For the given background range, the estimated scan MDC range for the hand-held gas proportional detector was $1,330 \mathrm{dpm} / 100 \mathrm{~cm}^{2}$ to $1,790 \mathrm{dpm} / 100 \mathrm{~cm}^{2}$ for $\mathrm{Sr}-90$ and 7,980 $\mathrm{dpm} / 100 \mathrm{~cm}^{2}$ to $10,720 \mathrm{dpm} / 100 \mathrm{~cm}^{2}$ for $\mathrm{C}-14$.

\section{Surface Activity Measurements}

Measurements of total alpha and total beta surface activity levels were performed using gas proportional and GM detectors with portable ratemeter-scalers. Based on the low efficiency of the gas proportional detectors for gamma radiation and since alpha activity was not detected at

\footnotetext{
${ }^{1}$ NUREG-1507. Minimum Detectable Concentrations With Typical Radiation Survey Instruments for Various Contaminants and Field Conditions. US Nuclear Regulatory Commission. Washington, DC; June 1998. 
the elevated beta activity measurement locations, all recorded beta events were assumed to be due to beta particles, only. Surface activity measurements were performed on floors, lower walls, upper walls, some equipment, and at locations of elevated direct radiation, using gas proportional detectors coupled to ratemeter-scalers.

Count rates (cpm), which were integrated over one minute with the detector held in a static position, were converted to activity levels $\left(\mathrm{dpm} / 100 \mathrm{~cm}^{2}\right)$ by dividing the net rate by the total efficiency $\left(\epsilon_{\mathrm{i}} \times \epsilon_{\mathrm{s}}\right)$ and correcting for the active area of the detector. The $2 \pi$ instrument efficiency factors $\left(\epsilon_{\mathrm{i}}\right)$ were as follows: alpha efficiency factor was 0.39 for the gas proportional detectors calibrated to Th-230; beta efficiency factors were 0.31 and 0.47 for the gas proportional detectors calibrated to $\mathrm{C}-14$ and Sr-90, respectively. The source efficiency factor $\left(\epsilon_{\mathrm{s}}\right)$ was 0.25 for alpha and $\mathrm{C}-14$ and 0.5 for Sr-90. The total alpha, C-14 beta, and Sr-90 beta efficiency factors for the gas proportional detectors were $0.10,0.08$, and 0.24 , respectively. For the modified GM detector, the total beta efficiency factor was 0.19 .

Because different building materials (poured concrete, brick, wood, steel, etc.) may have different background levels, average background count rates were determined for each material encountered in the surveyed area at a location of similar construction and having no known radiological history.

The alpha activity background count rates for the gas proportional detector averaged $1 \mathrm{cpm}$ for all surfaces. The beta activity background count rates for the gas proportional detector averaged $381 \mathrm{cpm}$. The physical probe area for the gas proportional detector was $126 \mathrm{~cm}^{2}$. Using efficiencies derived from a Sr-90 calibration source and comparing to the Sr-90 guideline proved to be the most conservative approach for evaluating surface activity.

\section{$\underline{\text { Removable Activity Measurements }}$}

Removable gross alpha and gross beta activity levels were determined using numbered filter paper disks, $47 \mathrm{~mm}$ in diameter. Moderate pressure was applied to the smear and approximately $100 \mathrm{~cm}^{2}$ of the surface was wiped. Smears were placed in labeled envelopes with the location and other pertinent information recorded. 
For tritium, C-14, and Sr-90 determination, a second smear was moistened with deionized water and an adjacent $100 \mathrm{~cm}^{2}$ was wiped. The smear was then sealed in a labeled liquid scintillation vial with the location and pertinent information recorded.

\section{Analytical Procedures}

\section{Gross Alpha/Beta}

Smears were counted on a low-background gas proportional system for gross alpha and gross beta activity. The MDCs of the procedure were $9 \mathrm{dpm} / 100 \mathrm{~cm}^{2}$ for gross alpha and $15 \mathrm{dpm} / 100$ $\mathrm{cm}^{2}$ for gross beta.

\section{Liquid Scintillation}

Smears were counted in a liquid scintillation counter for low-energy beta activity to determine $\mathrm{H}-3, \mathrm{C}-14$, and Sr-90 activity - typical MDCs for the procedures are 22,8 , and $44 \mathrm{dpm} / 100 \mathrm{~cm}^{2}$, respectively. 
APPENDIX C

\section{SUMMARY OF DEPARTMENT OF ENERGY \\ RESIDUAL RADIOACTIVE MATERIAL GUIDELINES}




\section{APPENDIX C}

\section{RESIDUAL RADIOACTIVE MATERIAL GUIDELINES SUMMARIZED FROM DOE ORDER 5400.5 (DOE 1990)}

\section{BASIC Dose Limits}

The basic dose limit for the annual radiation (excluding radon) received by an individual member of the general public is $100 \mathrm{mrem} / \mathrm{yr}$. In implementing this limit, DOE applies as low as reasonably achievable principles to set site-specific guidelines.

\section{External Gamma Radiation}

The average level of gamma radiation inside a building or habitable structure on a site that has no radiological restriction on its use shall not exceed the background level by more than $20 \mu \mathrm{R} / \mathrm{h}$ and will comply with the basic dose limits when an appropriate-use scenario is considered.

\section{Surface Contamination Guidelines}

Allowable Total Residual Surface Contamination $\left(\mathrm{dpm} / 100 \mathrm{~cm}^{2}\right)^{\mathrm{a}}$

Radionuclides $^{\mathrm{b}}$

Transuranics, Ra-226, Ra-228, Th-230 Th-228, Pa-231, Ac-227, I-125, I-129

Th-Natural, Th-232, Sr-90, Ra-223, Ra-224, U-232, I-126, I-131, I-133

U-Natural, U-235, U-238, and associated decay products

Beta-gamma emitters (radionuclides with decay modes other than alpha emission or spontaneous fission) except Sr-90 and others noted above

Average $^{\mathrm{c}, \mathrm{d}} \quad$ Maximum $^{\mathrm{d,e}} \quad$ Removable $^{\mathrm{d}, \mathrm{f}}$

100

300

20

1,000

3,000

200

$5,000 \alpha \quad 15,000 \alpha \quad 1,000 \alpha$

$5,000 \beta-\gamma \quad 15,000 \beta-\gamma \quad 1,000 \beta-\gamma$ 
a As used in this table, dpm (disintegrations per minute) means the rate of emission by radioactive material as determined by correcting the counts per minute measured by an appropriate detector for background, efficiency, and geometric factors associated with the instrumentation.

${ }^{b}$ Where surface contamination by both alpha- and beta-gamma-emitting radionuclides exists, the limits established for alpha- and beta-gamma-emitting radionuclides should apply indepen dently.

${ }^{\mathrm{c}}$ Measurements of average contamination should not be averaged over an area of more than 1 $\mathrm{m}^{2}$. For objects of less surface area, the average should be derived for each such object.

d The average and maximum dose rates associated with surface contamination resulting from beta-gamma emitters should not exceed $0.2 \mathrm{mrad} / \mathrm{h}$ and $1.0 \mathrm{mrad} / \mathrm{h}$, respectively, at a depth of $1 \mathrm{~cm}$.

e The maximum contamination level applies to an area of not more than $100 \mathrm{~cm}^{2}$.

${ }^{f}$ The amount of removable radioactive material per $100 \mathrm{~cm}^{2}$ of surface area should be determined by wiping an area of that size with dry filter or soft absorbent paper, applying moderate pressure, and measuring the amount of radioactive material on the wipe with an appropriate instrument of known efficiency. When removable contamination on objects of surface area less than $100 \mathrm{~cm}^{2}$ is determined, the activity per unit area should be based on the actual area and the entire surface should be wiped. The numbers in this column are maximum amounts. 